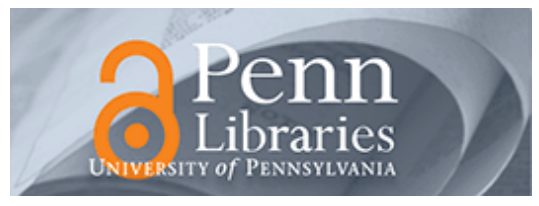

University of Pennsylvania

ScholarlyCommons

Operations, Information and Decisions Papers

Wharton Faculty Research

$11-2012$

\title{
Unsure What the Future Will Bring? You May Overindulge: Uncertainty Increases the Appeal of Wants Over Shoulds
}

Katherine L. Milkman

University of Pennsylvania

Follow this and additional works at: https://repository.upenn.edu/oid_papers

Part of the Applied Behavior Analysis Commons, Health Psychology Commons, Other Social and Behavioral Sciences Commons, and the Personality and Social Contexts Commons

\section{Recommended Citation}

Milkman, K. L. (2012). Unsure What the Future Will Bring? You May Overindulge: Uncertainty Increases the Appeal of Wants Over Shoulds. Organizational Behavior and Human Decision Processes, 119 (2), 163-176. http://dx.doi.org/10.1016/j.obhdp.2012.07.003

This paper is posted at ScholarlyCommons. https://repository.upenn.edu/oid_papers/22

For more information, please contact repository@pobox.upenn.edu. 


\title{
Unsure What the Future Will Bring? You May Overindulge: Uncertainty Increases the Appeal of Wants Over Shoulds
}

\begin{abstract}
This paper examines the effect of uncertainty about the future on whether individuals select want options (e.g., junk foods, lowbrow films) or instead exert self-control and select should options (e.g., healthy foods, highbrow films). Consistent with the ego-depletion literature, which suggests that self-control resembles an exhaustible muscle, coping with uncertainty about what the future may bring reduces selfcontrol resources and increases individuals' tendency to favor want options over should options. These results persist when real uncertainty is induced, when the salience of naturally-arising uncertainty is heightened and when individuals are able to make choices contingent upon the outcomes of uncertain events. Overall, this work suggests that reducing uncertainty in a decision maker's environment may have important spillover effects, leading to less impulsive choices.
\end{abstract}

\section{Keywords}

Want/should conflict, self-control, uncertainty, ego depletion

\section{Disciplines}

Applied Behavior Analysis | Health Psychology | Other Social and Behavioral Sciences | Personality and Social Contexts 


\title{
Unsure What the Future Will Bring? You May Overindulge: Uncertainty Increases the Appeal of Wants over Shoulds
}

\author{
Katherine L. Milkman ${ }^{1}$ \\ The Wharton School, University of Pennsylvania, Philadelphia, Pennsylvania 19104 \\ kmilkman@wharton.upenn.edu
}

This paper examines the effect of uncertainty about the future on whether individuals select want options (e.g., junk foods, lowbrow films, less cash now) or should options (e.g., healthy foods, highbrow films, more cash later). As predicted by the dual systems theory of want/should conflict, uncertainty about what the future may bring increases individuals' tendency to favor want options over should options, and these results hold even when individuals are able to make choices contingent upon the outcomes of uncertain events. These results cannot be explained by reason-based choice and persist both when real uncertainty is induced and when the salience of natural uncertainty is heightened for a decision maker through a directed writing task. Overall, this work suggests that reducing uncertainty in a decision maker's environment may have a "halo effect", leading to less impulsive choices. Implications for theories of want/should conflict, managers, policy makers, and individuals are discussed.

Last Revised: May 23, 2010

\footnotetext{
${ }^{1}$ I thank Max Bazerman, John Beshears, Howard Kunreuther, Karim Kassam, David Laibson, Kathleen McGinn, David Parkes, Maurice Schweitzer, Jack Hershey, as well as seminar participants at London Business School, the University of Southern California, Harvard University, Ohio State University and the University of Pennsylvania for helpful feedback on this paper. I also thank my research assistants Jessica Matthews, Vanessa Schneider, Liliana Urrutia, and Sammy Kim for their help collecting data and Bill Simpson for his technical expertise. Finally, I thank Harvard Business School and The Wharton School for funding support.
} 


\section{INTRODUCTION}

During the 2008-2009 economic crisis, which dramatically increased uncertainty in the lives of many Americans, the New York Times reported on skyrocketing sales of candy as other consumer expenditures plummeted (Haughney, 2009). To justify why he had increased his candy consumption during the period in question, one man interviewed by the Times explained “there's nothing more stressful than growing financial insecurity everywhere”. Often in our lives we face uncertainty about what the future will bring. Will our stock market portfolio move up or down tomorrow? Will our boss assign us to work on project A or project B? When such uncertainty hangs over us, it may systematically reduce our ability to exert self-control and make choices we know we should given our long-term interests rather than opting for what we viscerally want (e.g., candy).

This paper examines how uncertainty in a decision maker's environment affects her likelihood of engaging in indulgences. A series of studies demonstrate that when people choose between want and should options in the face of uncertainty, they are more likely to select want options. These findings have implications for managers, policy makers and marketers interested in finding ways to alter others' likelihood of making should choices as well as for individuals interested in increasing their own ability to exert self-control. These findings also have theoretical implications, providing support for a dual systems model of why certain situational factors systematically influence whether individuals favor want or should options.

Previous research has shown that when our ability to reason through choices in a cool, deliberate manner is weakened, the likelihood that we will reach for wants (e.g., junk foods and lowbrow films) over shoulds (e.g., healthy foods and highbrow films) increases (Shiv and Fedorkhin, 1999). Research on the disjunction effect (Tversky and Shafir, 1992; Shafir and 
Tversky, 1992; Shafir, 1994) has also demonstrated that uncertainty leads people to make systematically different choices than they would given any sure outcome. This paper extends the literature on want/should conflict by examining how uncertainty affects whether people make want or should choices. Before presenting five laboratory experiments and an analysis of archival field data to explore this question, I review the relevant past research on want/should conflict and the disjunction effect.

\section{Past Research on Want/Should Conflict}

Often, individuals face internal conflict when making decisions, leading them to waffle when attempting to choose between an option they viscerally and impulsively want (e.g., pizza for lunch, to spend their paycheck all at once) and something they feel they should select (e.g., salad for lunch, to save their money for retirement). To explain what causes individuals to favor should options over want options or visa versa in different contexts, it has been proposed that individuals employ dual systems for decision making (Thaler and Shefrin, 1981; Schelling, 1984; Bazerman, Tenbrunsel and Wade-Benzoni, 1998; Metcalfe and Mischel, 1999; Shiv and Fedorikhin, 1999; Milkman, Rogers and Bazerman, 2008) - a hot, affective, impulsive system, which has been labeled "the want self", and a cool, cognitive, controlled system, which has been labeled "the should self" (Bazerman et al., 1998). The dual selves theory argues that the should self is influenced primarily by reflection about what ought to be done given one's long-term interests (e.g., saving for retirement, watching intellectual movies, and eating healthy foods), while the want self is driven by emotional reactions in the moment when a decision will take effect.

Want options (favored by the want self) provide more immediate pleasure to an individual than should options, but less net future value (Milkman et al., 2008). Options that are 
similar to shoulds have also been referred to as "cognitive", "utilitarian", "virtue", "affect-poor" and "necessity" options, while wants have alternatively been referred to as "affective", "hedonic", "vice", "affect-rich", and "luxury" options (see Khan, Dhar and Wertenbroch, 2005 for a review). Early research on want/should conflict primarily focused on tradeoffs between accepting a small amount of money immediately (a want) versus waiting patiently for a considerably larger payoff after some time delay (a should) (Ainslie and Haendel, 1983; King and Logue, 1987; Kirby, 1997; Kirby and Herrnstein, 1995; Kirby and Marakovic, 1996; McClure et al., 2004; Thaler, 1981). More recent research has extended this early work on monetary discounting to examine a wider range of domains involving want/should conflicts, including decisions between highbrow (should) and lowbrow (want) films (Read, Loewenstein and Kalyanaraman, 1999; Milkman et al., 2009; Khan and Dhar, 2007), healthy (should) and unhealthy (want) foods (Read and van Leeuwen, 1998; Shiv and Fedorkhin, 1999; Khan and Dhar, 2007; Milkman et al., 2010), as well as investment (should) and leisure (want) magazines (Oster and Scott Morton, 2005; Khan and Dhar, 2007), to name a few.

According to the "dual selves" theory, situations that trigger affective, visceral desires (Loewenstein, 1996), or place a strain on cognitive resources (Shiv and Fedorkhin, 1999), increase the likelihood that people will make want choices. Strains placed on cognitive resources are hypothesized to weaken the cognitive should self, giving the want self an advantage in decision making. Affective, visceral triggers are hypothesized to strengthen the will of the impulsive want self, again handing the want self an advantage in decision making.

In contrast, the dual selves theory predicts that situations that weaken impulses or strengthen cognitive systems ought to increase the likelihood that people will make should choices. Any boost to cognitive resources is hypothesized to provide an advantage to the 
thoughtful should self over the far less cerebral want self in conflicted decision making. On the other hand, if impulses are dampened, this is hypothesized to weaken the want self, providing an advantage to the should self in decision making.

A number of factors have been shown to systematically alter whether individuals prefer want or should options in ways that are consistent with the predictions of the dual selves theory. One factor that has been linked theoretically and empirically to increased influence of the want system is immediacy. The dual selves theory predicts that decision makers choosing for now will favor wants over shoulds more often than decision makers choosing for later because visceral factors (e.g., hunger, emotional desires, etc.), which trigger and therefore enhance the power of the want system in decision making, will only influence choices made for the present (Milkman et al., 2008). Consistent with this theory, numerous studies have confirmed that individuals are more inclined to behave impulsively and favor wants over shoulds when making choices for now rather than later (Read and Van Leeuwen, 1998; Read, Loewenstein and Kalyanaraman, 1999; Milkman, Rogers and Bazerman, 2009). Neurological research has shown that parts of the limbic system are activated by choices involving immediately available rewards (wants) that are not activated by choices involving delayed rewards (shoulds) (McClure, Laibson, Loewenstein, and Cohen, 2004).

A second factor that has been linked theoretically and empirically to increased influence of the want system is concrete thinking. The dual systems theory predicts that concrete thinking will trigger the want self because concrete conceptualizations emphasize viscerally tempting characteristics of a choice (e.g., taste, smell, and consequent emotions). As predicted by this theory, individuals have been shown to prefer wants over shoulds at a higher rate when they are 
primed to engage in more concrete and less abstract thinking (Fujita, Trope, Liberman and Levin-Sagi, 2006).

According to the dual systems theory, evaluating choices jointly rather than separately will increase the influence of the should self by highlighting the need for a direct comparison of options and thus triggering an individual's cognitive systems (Bazerman et al., 1998). As predicted by this model, when choices are evaluated jointly rather than separately, the popularity of should options over want options is increased (Bazerman, Loewenstein and White 1992; Irwin, Slovic, Lichtenstein and McCelland 1993; Kahneman and Ritov, 1994; Bazerman, Schroth, Shah, Diekmann, and Tenbrunsel 1994; Bazerman, Moore, Tenbrunsel, Wade-Benzoni and Blount, 1999).

The dual systems theory also predicts that the should self can be weakened by cognitive strain, leading to increased take-up of wants. Consistent with this prediction, Shiv and Fedorkhin (1999) demonstrated that subjects in an experiment who were placed under high cognitive load (by memorizing a seven digit number) were significantly more likely to prefer cake (a want option) over fruit salad (a should option) than subjects who were placed under low cognitive load (by memorizing a two digit number).

Another way of stressing and thereby reducing the effectiveness of the cognitive, should self would be to exhaust it through repeated use. It has been demonstrated that after engaging their should systems by exerting self-control in one domain, experimental subjects are less likely to engage their "depleted" and exhausted should systems again and more likely to select want options (Baumeister, Bratslavsky, Muraven, and Tice, 1998; Muraven, Tice, and Baumeister, 1998). Although the authors of this research have proposed a theory of self-control as a muscle to explain their results (Muraven and Baumeister, 2000), their findings are also predicted by the 
broader dual-selves theory. Under the dual systems theory, depletion can be viewed as a way of straining and weakening the should self through repeated exertion and thereby reducing its ability to override the desires of the want self.

Similarly, when a decision maker lacks a strong, cognitive rationale for exerting selfcontrol and making a should choice, the dual systems theory predicts the should self will be weakened, providing the want self with an added advantage. Consistent with this prediction, it has been demonstrated that when a decision maker could view herself as "licensed" to make a want choice either because future should choices are anticipated or past should choices are recalled, a decision maker is more likely to select want options (Khan and Dhar, 2006; Khan and Dhar, 2007).

Although uncertainty is present in many important decision making environments, its impact on want/should conflict has not previously been studied. To predict what impact uncertainty might have on the want and should selves and therefore on the outcome of wants/should conflicts, it is necessary to consider the impact of uncertainty on cognitive reasoning and visceral responses.

\section{Past Research on the Disjunction Effect}

Savage's (1954) sure-thing principle states that if an individual would prefer the same option given any possible outcome of an uncertain event, then an individual should also prefer that option before the uncertain outcome is revealed. Such consequentialism in choice under uncertainty is a cornerstone of Expected Utility Theory (Mas-Colell, Whinston, and Green, 1995). However, research by Tversky and Shafir (1992; 1994) has demonstrated that when people would prefer an option A to an option B given any of the possible outcomes of an uncertain event, they will not necessarily select option A before their uncertainty is resolved. 
Tversky and Shafir find that people prefer not to take action when they face uncertain outcomes (Tversky and Shafir, 1992). For example, the authors find that while a majority of subjects in an experiment would accept a second gamble if they had either won or lost a first gamble, the majority would reject a second gamble - preferring inaction - before learning the outcome of the first (Tversky and Shafir, 1992). The aversion to action in the face of irrelevant uncertainty is so strong that decision makers will actually pay $\$ 5$ to defer a choice about whether or not to buy a trip package when unsure if they passed an exam until after learning the outcome even when they would make the same choice (to purchase the package) regardless of their exam performance (Tversky and Shafir, 1992).

Tversky and Shafir propose that in the face of uncertainty, decision makers have difficulty reasoning through their choices, and this complexity systematically alters their selections, leading to inaction (Tversky and Shafir, 1992; Shafir and Tversky, 1992; Shafir, 1994). If uncertainty reduces decision makers' ability to reason logically through their decisions and weakens their cognitive resources, it may systematically alter preferences for options that provide instant versus delayed gratification - the topic addressed in this paper. Specifically, by weakening the should self, uncertainty may empower the want self to exert increased influence over decisions.

In addition to proposing that uncertainty introduces added decision complexity, which alters choices, Tversky and Shafir also put forward a theory of reason-based choice as an explanation for their findings (Tversky and Shafir, 1992; Shafir and Tversky, 1992; Shafir, 1994; Shafir, Simonson and Tversky, 1993). Specifically, they speculate that participants in their studies need a reason to justify making an active decision (e.g., placing a gamble or purchasing a trip package rather than opting out). When participants know they have won or lost a gamble (or 
passed or failed an exam), they can construct a reason based on that known outcome for a subsequent active choice far more easily than when they are uncertain about their gamble's (or exam's) result. Tversky and Shafir argue an explanation for the disjunction effect is that when faced with uncertainty, decision makers "often do not consider appropriately each of the relevant branches of the decision tree" (Shafir and Tversky, 1992). To examine whether a failure to appropriately consider each of the branches of an uncertain decision tree could account for the findings in this paper, one study (Study 4) employs a design that forces participants to make reason-based choices.

\section{Overview of Studies}

Combining the dual systems theory of want/should conflict with past research on the disjunction effect indicating that uncertainty makes it more difficult for a decision maker to reason systematically through her options leads to the prediction that uncertainty in one's environment will produce an increased preference for wants. If uncertainty in a decision environment increases the complexity of the choice an individual must make, uncertainty would be expected to weaken the cognitive, should self, leading to increased take-up of wants. Across a series of six studies, this paper thus tests the following hypothesis drawn from the dual selves model of want/should conflict: Uncertainty in a decision environment leads to increased take-up of want options over should options.

Study 1 is a scenario study demonstrating that uncertainty increases the rate at which people choose want options over should options in the domain of film choice, and Study 2 replicates this effect when subjects instead make choices about what to have for dessert. Study 3 demonstrates that these results hold when subjects make real rather than hypothetical choices. Study 3 also demonstrates that these results hold under cognitive load but are neither mediated 
nor moderated by success retaining cognitively taxing information or by self-reported cognitive effort. This suggests that uncertainty affects want/should choice through a different channel than the cognitive load introduced by Shiv and Fedorkhin (1999) in previous want/should research. Study 4 demonstrates that uncertainty increases take-up of wants even when choices are made contingent upon the outcome of an uncertain event, ruling out a Tversky and Shafir $(1992 ; 1994)$ reason-based choice explanation for the findings of Studies 1-3. Study 4 also helps to rule out the possibility that the fit between want/should options and an individual's choice context might influence decisions since the choice context is identical in all conditions of the experiment, and it is still the case that want choices enjoy more popularity under uncertainty. Finally, Study 4 provides suggestive evidence that the effects of uncertainty are dependent on the types of uncertain outcomes an individual faces. Study 5 demonstrates that merely heightening the salience of naturally-occurring sources of uncertainty increases the rate at which people discount future cash flows, highlighting again that uncertainty produces an increased preference for wants when no alterations are made to the fit between available options and a choice's context. Finally, Study 6 provides suggestive evidence that uncertainty may influence want/should decisions in the field. An analysis of archival data from a large online grocer to reveals that added uncertainty in a decision maker's environment produced by a more volatile economic climate is associated with increased spending on want goods and decreased spending on should goods.

\section{STUDY 1}

In Study 1, I compare the rate at which people select want options over should options in the presence and absence of uncertainty.

\section{Method}

Participants 
227 participants were recruited to participate in this five minute scenario study on a large college campus in the Northeastern United States in exchange for small prizes.

\section{Procedure}

Participants were asked to imagine that their roommate was setting them up on a blind date with a co-worker. Whichever of two of their roommate's co-workers was available would take the participant to the movies. Profiles describing the two possible dates (who were given the gender neutral names Devon and Addison) were provided (see Figure 1), and participants were told the chances were $50 \%$ that Devon would be available and $50 \%$ that Addison would be available. Participants' instructions were to choose a movie to see during their date. The options were described as "a documentary about a fairly esoteric topic that has been called 'a bit dull but highly educational and enlightening' or an action film with attractive movie stars that has been called 'empty but highly entertaining'." Participants were told "You feel conflicted because you think you should see the documentary but you really want to see the action film."

\begin{tabular}{|l|l}
\hline Possibility \#1: Devon & Possibility \#2: Addison \\
\hline Style: Preppy & Style: Scholarly \\
Hair: Brown, Straight & Hair: Red, Curly \\
Eyes: Brown & Eyes: Blue \\
Attractiveness Rating $(1-10$ scale $): 6$ & Attractiveness Rating $(1-10$ scale $): 7$ \\
Fun to Be Around Rating $(1-10$ scale $): 9$ & Fun to Be Around Rating $(1-10$ scale $): 5$ \\
Home: Small town on the West Coast & Home: Big city on the East Coast \\
Education: Law Degree & Education: Ph.D. in Philosophy \\
Interests: Politics, Sports, Travel & Interests: Theories of Religion, Antiques \\
\hline
\end{tabular}

Figure 1. Description of possible dates (with gender neutral names) provided to participants.

One third of participants (those randomly assigned to the Devon condition) were then told that their date would be with Devon and asked to choose between seeing an action film and a documentary. One third of participants (those in the Addison condition) were told that their date would be with Addison and asked to choose between seeing an action film and a documentary. A final third of participants were assigned to the uncertainty condition and were told the odds 
remained 50\% that they would go on a date with Devon and 50\% that they would go on a date with Addison. However, they would have to choose between seeing an action film and a documentary before the resolution of this uncertainty. ${ }^{2}$ See Appendix A for complete study materials.

\section{Results and Discussion}

Consistent with the prediction of the dual selves theory of want/should conflict, participants facing uncertainty about their date's identity were more likely to choose the action (want) film over the documentary (should) film (81\%) than those who were certain of their date's identity (Devon condition - 50\%; Addison condition - 61\%). In a logit to predict should film selection, indicator variables for both the Devin and Addison conditions are significant $\left(\beta_{\text {Devin_condition }}=1.46 ; \mathrm{p}<0.01 ; \beta_{\text {Devin_condition }}=0.99 ; \mathrm{p}<0.01 ; \mathrm{N}=227 ; \mathrm{LR} \mathrm{Chi}^{2}(2)=17.0\right)$. It should be noted that the peculiarities of the profiles of Devon and Addison may have played some role in this finding. The following study addresses this concern.

\section{STUDY 2}

Study 2 examines whether the findings from Study 1 replicate when the uncertainty faced pertains to possible goods an individual could receive rather than people an individual could spend time with.

\section{Method}

Participants

175 participants were recruited to participate in this five minute scenario study on two college campuses in the Northeastern United States in exchange for small prizes.

\section{Procedure}

\footnotetext{
${ }^{2}$ This three cell design is modeled on that used by Tversky and Shafir (1992) to study the disjunction effect.
} 
Participants were asked to imagine that their roommate would pick up pizza for dinner from their favorite pizza place, which only sells one type of pie each night. They were told there was a $50 \%$ chance that tonight's pizza would be a carne asada pizza and a $50 \%$ chance that it would be a pesto chicken pizza (see Figure 2 for descriptions provided). Participants were then informed that it would be up to them to choose a dessert so their roommate could purchase that as well. The options available were fresh fruit salad or brownies, and participants were told "You are trying to lose weight, so you know you probably should choose the fresh fruit salad, but fresh brownies are what you viscerally want."

\begin{tabular}{|l|l|}
\hline & $\begin{array}{l}\text { Possibility \#1: Carne Asada Pizza } \\
\text { Grilled steak, fire-roasted mild chilies, } \\
\text { onions, cilantro pesto, Monterey Jack, } \\
\text { and Mozzarella cheeses. Topped with } \\
\text { fresh tomato salsa and cilantro. Served } \\
\text { with a side of tomatillo salsa. }\end{array}$ \\
\hline Figure 2. Description of possible pizzas shown to participants. \\
\hline Fis
\end{tabular}

One third of participants (those randomly assigned to the carne asada condition) were told that the available pizza would be carne asada pizza and asked to choose a dessert. One third of participants (those in the pesto chicken condition) were told that the available pizza would be pesto chicken pizza and asked to choose a dessert. A final third of participants were assigned to the uncertainty condition, and they were told the odds were $50 \%$ that the available pizza would 
be carne asada and $50 \%$ that it would be pesto chicken pizza but that they would have to choose a dessert before the resolution of this uncertainty. See Appendix B for complete study materials.

\section{Results and Discussion}

Again, consistent with the prediction of the dual selves theory of want/should conflict, participants facing uncertainty about the type of pizza they would eat were more likely to choose brownies (the want dessert) over fruit salad (the should dessert) (82\%) than those who were certain of the type of pizza available (carne asada condition - 58\%; pesto chicken condition59\%). In a logit to predict should dessert selection, indicator variables for both the carne asada and pesto chicken conditions are significant $\left(\beta_{\text {carne_asada_condition }}=1.24 ; \mathrm{p}<0.01\right.$;

$\left.\beta_{\text {pesto_chicken_condition }}=1.17 ; \mathrm{p}<0.01 ; \mathrm{N}=175 ; \operatorname{LR~Chi}^{2}(2)=10.6\right)$.

\section{STUDY 3}

Study 3 examines whether the findings of Studies 1 and 2 persist when individuals make real rather than hypothetical choices. Study 3 also examines whether the effect of uncertainty persists when individuals are subjected to cognitive load (in the form of memorizing a ten digit number, following Shiv and Fedorkhin, 1999). If the effect of uncertainty is simply to induce cognitive load, then it should be the case that uncertainty either has no meaningful affect on people under extreme cognitive load or that people's success retaining memorized ten digit numbers (or reported cognitive load) will mediate the effect of uncertainty on take-up of want options. However, if uncertainty influences want/should conflict irrespective of cognitive load, that would suggest that uncertainty and cognitive load influence want/should choice through independent processes.

\section{Method}

\section{Participants}


136 students were recruited through campus advertisements at a large university in the Mid-Atlantic region of the United States. These students were paid $\$ 10$ for their participation in this study, which required them to take a five minute survey the evening before participating in a one hour in-person study. $84 \%$ of participants who took part in the online survey completed the in-person portion of the study.

\section{Procedure}

Participants who signed up to take part in a series of in-person studies in a University campus behavioral lab over the course of one hour were prompted to take a short online survey the evening before arriving at the lab. This online survey first subjected participants to cognitive load by asking them to do their best to memorize a ten-digit number (following Shiv and Fedorikhin, 1999). Next, participants were randomly assigned to one of three conditions. One third of participants (those randomly assigned to the uncertainty condition) were told that the following day in the lab a coin flip would determine which of two radio stations they would listen to for fifteen minutes: an oldies music radio station or a pop music radio station. One third of participants (those randomly assigned to the pop condition) were told that the following day in the lab they would listen to a pop music radio station for fifteen minutes. The final third of participants (those randomly assigned to the oldies condition) were told that the following day in the lab they would listen to an oldies music radio station for fifteen minutes.

All participants were then prompted to select an article to read while listening to music during the following day's laboratory session. Their article choice was described as a decision between "(a) a magazine article about a fairly esoteric topic that has been called 'a bit dull but highly educational and enlightening' or (b) an article about a popular topic that has been called 
'empty but highly entertaining"'. Choice (a) fit the definition of a should option, while choice

(b) fit the definition of a want option.

After making their article selection, participants were prompted to do their best to recall the 10 digit number they had been asked to memorize at the survey's outset. Finally, participants were prompted to rate how cognitively taxing they found the choice between articles (a) and (b) on a Likert scale ranging from " 1 - not at all cognitively taxing" to " 7 - extremely cognitively taxing". See Appendix C for complete study materials.

\section{Results and Discussion}

Consistent with the prediction of the dual selves theory of want/should conflict, participants facing uncertainty about the type of music they would listen to were more likely to choose the empty but highly entertaining article (the want choice) over the dull but highly educational article (the should choice) (76\%) than those who were certain of the type of music they would listen to (pop condition - 54\%; oldies condition - 62\%). In a logistic regression to predict choice of the should article, several measures of cognitive load collected in this study are included as control variables: (1) a participant's self-report of how cognitively taxing he or she found the decision of which article to read on a 1-7 scale, (2) dummies indicating whether the participant correctly remembered each digit of the 10-digit number he or she was asked to memorize, and (3) the number of seconds it took the participant to read about the web radio station (or potential stations) he or she would listen to the next day before clicking forward in the survey. As reported in Table 1, a dummy variable indicating that the participant was in the oldies condition is a significant positive predictor of selecting the should article $(\mathrm{p}<0.05)$, and dummy variable indicating that the participant was in the pop condition is a marginally significant positive predictor of selecting the should article $(\mathrm{p}<0.10)$. This finding lends 
additional support to the conclusions of Studies 1 and 2 that uncertainty increases the probability that individuals will select wants over shoulds.

Table 1. Below are the results of a logit regression analysis to predict the selection of a should magazine article including predictors to indicate a participant's experimental condition and experienced cognitive load. Standard errors are in parentheses.

\begin{tabular}{lc}
\hline \hline & Should Article Selected \\
\cline { 2 - 2 } Pop condition & $1.00^{\star \star}$ \\
Oldies condition & $(0.50)$ \\
& $0.91^{\star}$ \\
Rating of cognitive tax & $(0.54)$ \\
& $0.27^{\star \star}$ \\
Seconds of contemplation & $(0.13)$ \\
& 0.04 \\
Dummies indicating retention of & $(0.04)$ \\
individual digits in memorized number & Yes \\
\hline Observations & 136 \\
Log likelihood & -79.57 \\
Pseudo R-Squared & 0.1156 \\
\hline \hline
\end{tabular}

*Significant at 10 percent level, **Significant at 5 percent level

With the exception of the dummy indicating whether a participant remembered the first digit of the 10-digit number she was asked to memorize at the study's outset, none of the collected measures of cognitive load included in these analyses are correlated with a subject's assignment to the uncertainty condition. In addition, none of the measures of cognitive load included in these analyses is a significant mediator of the relationship between assignment to the uncertainty condition and the likelihood of making a should choice. These results suggest that the effect of uncertainty on take-up of should options is not driven by the induction of the type of cognitive load identified by Shiv and Fedorikhin (1999). It is noteworthy that consistent with past research associating cognitive effort with take-up of should options (Shiv and Fedorikhin, 
1999), self-reported experienced cognitive load is a significant positive predictor of a participant's likelihood of selecting the should article (see Table 1).

The results of this study and of Studies 1 and 2 demonstrate that uncertainty increases take-up of should options. However, there are several alternative explanations for these findings besides the account that the presence of uncertainty makes wants more appealing. The first alternative involves a "hedging" explanation. If some people would prefer a want paired with one outcome but a should paired with the other, then the results of these two studies could be driven by people with split preferences who, in the face of uncertainty, prefer to assure themselves of a want rather than risk receiving a should without its appropriate complement. For example, in Study 2, carne asada pizza lovers might find fruit salad tolerable when paired with their favorite pizza but prefer brownies when forced to eat pesto chicken pizza. Facing an uncertain pizza dinner, people with such preferences might systematically "hedge" by guaranteeing themselves at least one indulgence (selecting brownies), perhaps due to regret aversion (Loomes and Sugden, 1982). The second alternative involves a reason-based choice explanation (Tversky and Shafir 1992; 1994). If individuals fail to think through the branches of their decision tree when facing uncertainty and are thus unable to construct a reason for making a choice under uncertainty, the lack of opportunity for reason-based decision making may drive want selections rather than uncertainty itself. Finally, the fit between want/should options and the choice context might influence decisions: if want options are more generically appealing than should options and people prefer generic solutions when two possible outcomes are presented rather than a single possibility, this could explain the findings presented in Studies 1-3.

\section{STUDY 4}


Study 4 attempts to replicate the findings of Studies 1, 2 and 3 in a context where the alternative "hedging," "reason-based choice," and "fit" explanations described above could not account for increased take-up of wants in the face of uncertainty. The new feature of Study 4 designed to rule out these possible alternative explanations is that participants facing uncertainty are prompted to make choices between want and should options contingent upon the outcome of an uncertain event. If participants are forced to consider each branch of a decision tree and to make decisions contingent on their branch, Tversky and Shafir's reason-based choice theory would predict no impact of uncertainty on preferences. Similarly, there would be no need for hedging in this situation nor would a participant ever face two possible alternatives rather than one leading to a preference for a more generic "fit".

Study 4 also extends Studies 1, 2 and 3 by exploring whether the types of options an individual faces uncertainty over (e.g., two similar or two different options on the want/should spectrum) affect whether uncertainty leads to increased take-up of wants. Facing uncertainty about similar outcomes should increase how difficult it is for a decision maker to reason through a decision tree by reducing the ease with which different, distinct outcomes can be imagined and evaluated (March and Simon, 1958). When uncertain potential outcomes are distinct from one another, mental simulations about what potential alternative futures will bring are easy - people know they will have one of two clearly distinguishable experiences. However, when the potential outcomes blend together, such mental simulations may lead to fuzzy and difficult to distinguish forecasts of what lies ahead. Thus, the effects of uncertainty are hypothesized to be enhanced under a dual systems model of want/should conflict when this additional strain is placed on the cognitive resources of the should self and reduced when decision makers face uncertainty pertaining to distinct outcomes. 


\section{Method}

\section{Participants}

31 students were recruited through advertisements in multiple campus newspapers at several large universities in the Northeastern United States. These students were paid $\$ 40$ for their participation in this two day study, which required one hour of their time on two successive weekdays. There was no attrition from this study - all participants who took part in the study on day one returned to complete the study on day two.

\section{Procedure}

On the first day of this study, participants were told that on the following day, they would spend one hour watching a television show assigned by the experimenter while eating a snack of their choice - either an apple (the should choice) or a package of M\&Ms (the want choice). All participants received descriptions of the concepts "want" and "should" and were asked to classify which was more of a want - an apple or a package of M\&Ms - and which was more of a should - an apple or a package of M\&Ms. Participants' responses confirmed that apples are perceived as shoulds while M\&Ms are perceived as wants. ${ }^{3}$

Half of the participants were randomly assigned to the certainty condition and were told which television show they would watch tomorrow as well as the title of another show from the available library that they would not be watching. The other half of participants were assigned to the uncertainty condition and were told the names of two television shows they might watch tomorrow and informed that a coin toss tomorrow would determine which show they would actually see. In both conditions, the two shows presented to participants were randomly selected

\footnotetext{
329 of 31 participants classified apples as shoulds and M\&Ms as wants and the remaining participants classified apples as both wants and shoulds.
} 
from the set of 136 hour-long television programs with episodes available for free viewing on www.hulu.com as of October 2008. ${ }^{4}$

Participants in both conditions were also randomly assigned to either see descriptions of two shows that were deemed similar on the want/should spectrum or two shows that were deemed extreme opposites on that spectrum. To determine what shows were similar and what shows were extreme opposites on this spectrum, two raters provided each television show with a want rating and a should rating on a 1 to 7 scale after reviewing concept definitions (see Appendix C). To create a single should minus want (SMW) rating for each show, want ratings were subtracted from should ratings (following Milkman et al., 2009 and Milkman et al., 2010). Across the 136 shows rated, SMW rater agreement was fair $(\alpha=0.44)$. Shows were divided into six equal-sized bins based on their average $S M W$ scores (see Appendix C), and participants either saw one show drawn randomly from the top (extreme should) bin and one show drawn from the bottom (extreme want) bin or two shows drawn randomly from the same bin.

After learning what show(s) they would either potentially or definitely see tomorrow, participants were prompted to make a binding choice about what snack to eat while watching television (an apple or a package of M\&Ms). Participants in the uncertainty condition were prompted to make their snack choices contingent upon the outcome of tomorrow's coin toss. In other words, participants selected what snack they would eat if the first of the two television shows they might watch were randomly selected tomorrow and also what snack they would eat if the second of those two shows were randomly selected. Snack choices could be identical or different for the two shows depending on the participant's preferences. Finally, after making their snack selections, participants completed a PANAS questionnaire to measure positive and

\footnotetext{
4 “Hulu - Watch your favorites. Anytime. For free.” www.hulu.com. Accessed October 24, 2008.
} 
negative affect (Watson, Clark and Tellegen, 1988). See Appendix D for complete study materials.

\section{Results and Discussion}

The results of this study are consistent with those of Studies 1, 2 and 3. Participants facing uncertainty about the television show they would watch tomorrow were more likely to choose M\&Ms (the want snack) over an apple (the should snack) (63\%) than those who were certain of the show they would be watching $(27 \%)$ when the rate of M\&M selection is averaged across the two contingent choices made by participants in the uncertainty condition to provide a single observation per participant. Including both choices made by each participant in the uncertainty condition in a logistic regression to predict M\&M selection with clustered standard errors to account for repeated observations of the same individual indicates that this difference is statistically significant $(\mathrm{z}=-2.04, \mathrm{p}<0.05 ; \mathrm{N}=47)$. This finding lends additional support to the hypothesis that uncertainty increases the probability that individuals will select wants over shoulds, as the decisions of participants in this contingent choice setting could not be explained by "hedging" or a desire for generic fit. Participants' decisions in this study also cannot be explained by a failure to engage in reason-based choice when facing uncertainty given the contingent nature of the choices made under uncertainty.

As illustrated in Figure 3, the detected effect appears to be driven by participants who faced uncertainty about which of two similar television shows they would watch tomorrow. In a logistic regression conducted to predict M\&Ms selection, including an indicator of whether a participant was in the uncertainty condition (1) or not (0), an indicator of whether a participant saw two similar television shows (1) or not (0), and an interaction between these variables, where robust standard errors were clustered at the individual level to account for repeated 
choices by the same individual in the uncertainty condition, the interaction term is significant ( $\mathrm{z}$ $=21.04, \mathrm{p}<0.01 ; \mathrm{N}=47)$.

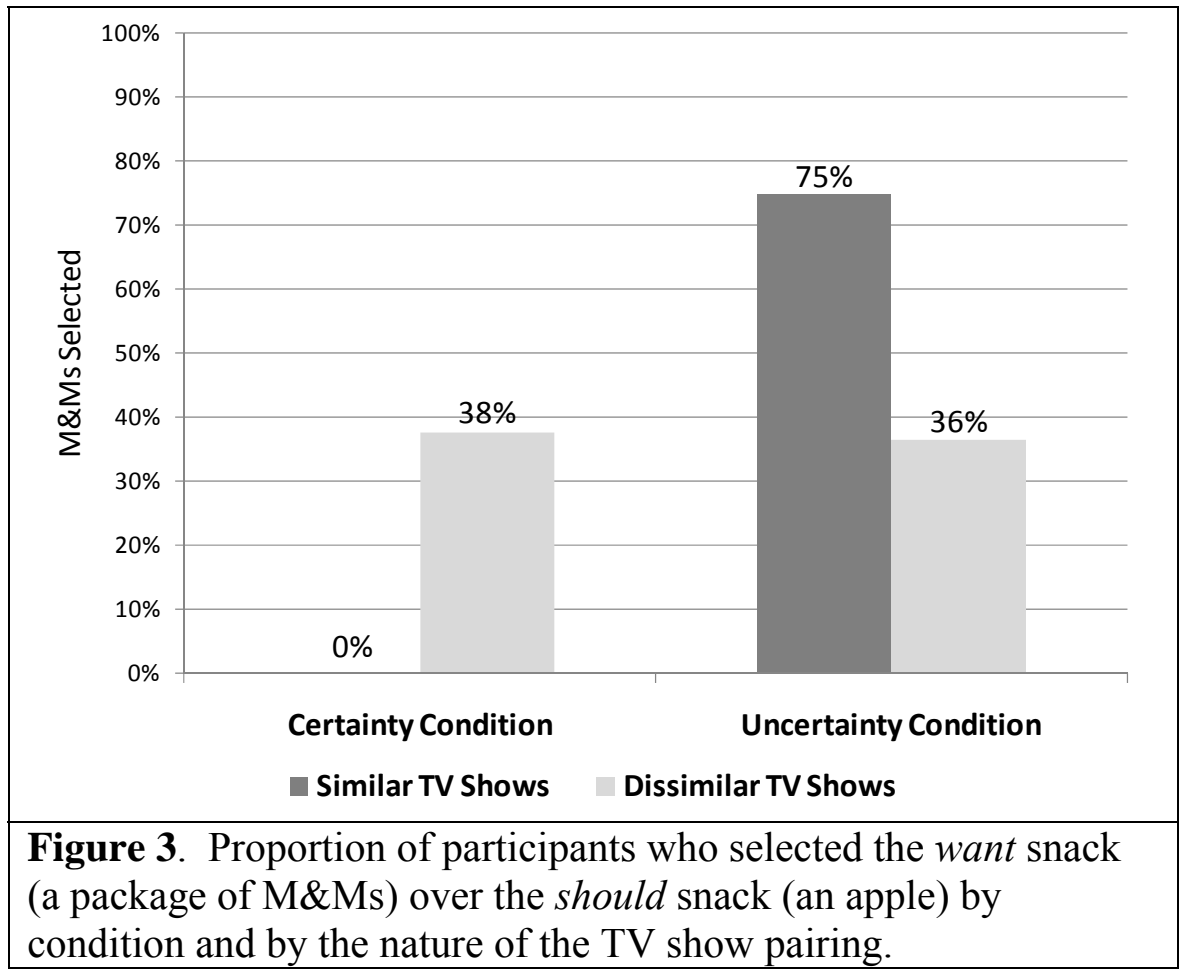

Finally, there is no evidence that participants' levels of positive or negative affect vary across conditions. Previous research has shown that uncertainty dampens positive and negative emotions felt in response to potential outcomes (Van Dijk and Zeelenberg, 2006), suggesting that different intensities of emotions induced by the certainty and uncertainty conditions in this experiment might explain the results described above. However, no significant differences by condition were detected for any of the 20 emotions measured by the PANAS scale (Watson et al., 1988).

\section{STUDY 5}

Study 5 examines whether an uncertainty salience induction shifts individuals towards favoring their want self over their should self and discounting future cash flows at a higher rate 
(a want behavior). Together with Study 4, this study helps to rule out the possibility that context effects or hedging can explain the impact of uncertainty on want/should choices.

\section{Method}

Participants

152 students were recruited through campus advertisements at a large university in the Mid-Atlantic region of the United States. These students were paid \$10 for completing a series of surveys over the course of an hour.

\section{Procedure}

Participants were randomly assigned to one of two conditions with equal probability - the uncertainty condition or the certainty condition. In both conditions, participants completed a directed-writing task designed to manipulate their feelings of uncertainty. The elicitation procedure employed was adapted from a procedure developed by Strack, Schwarz, and Gschneidinger (1985) to manipulate emotions and validated in several subsequent studies (see Keltner et al., 1993; Lerner and Keltner 2001; Tiedens and Linton, 2001; and Dunn and Schweitzer, 2005). The induction exercise asked participants to first "briefly describe three to five things that you are most [uncertain/certain] about." The following question asked participants to "describe in detail the one situation that has made you the most [uncertain/certain] you have been in your life, and describe it such that a person reading the description would become [uncertain/certain] just from hearing about the situation." After responding to these two questions, participants were exposed to the uncertainty salience manipulation employed in van den Bos (2001), which asked them to "describe the emotions that the thought of your [being uncertain/sitting in a quiet place (e.g., a park)] generally arouses in you" and to "write down, as 
specifically as you can, what you think physically will happen to you as you feel [uncertain/sit in a quiet place (e.g., a park)].”

After responding to this series of four questions designed to manipulate the salience of uncertainty, participants were asked to complete a discounting task (see Thaler, 1981; Benzion, Rapoport and Yagil, 1989). They were asked to indicate their preferences over a series of 20 monetary tradeoffs. Each tradeoff involved a choice between $\$ 10$ now and $\$ 10+X$ in one week, where $X$ was decremented from $\$ 5$ to $\$ 0.25$ in $\$ 0.25$ intervals. See Appendix F for complete study materials.

\section{Results and Discussion}

Consistent with the prediction of the dual selves theory of want/should conflict, participants in the uncertainty condition (for whom uncertainty salience was heightened) exhibited discount rates that were significantly steeper than participants in the certainty condition. On average, participants in the uncertainty condition were indifferent between $\$ 12.19$ in one week and $\$ 10$ now, while participants in the certainty condition were, on average, indifferent between $\$ 11.72$ in one week and $\$ 10$ now. An ordered logit to predict the minimum amount a participant would accept in one week over $\$ 10$ today with a dummy variable indicating whether a participant was in the uncertainty condition yields a significant, positive coefficient on the uncertainty condition dummy $\left(\beta_{\text {uncertainty_dummy }}=0.61 ; \mathrm{p}<0.05 ; \mathrm{N}=152 ; \operatorname{LR~Chi}^{2}(1)=4.5\right){ }^{5}$ These findings suggest that uncertainty can influence want/should conflict without altering the fit between available wants and shoulds and the context in which they are being selected.

\section{STUDY 6}

\footnotetext{
${ }^{5}$ As in Study 4, responses to a PANAS questionnaire (Watson et al., 1988) administered after the study yielded no evidence that participants' levels of positive or negative affect varied across conditions.
} 
Study 6 examines whether volatility in financial markets is associated with increased spending on want groceries and decreased spending on should groceries by the customers of a large online grocer. Analyses are conducted within-customer, examining changes in purchases by the same consumers over time as a function of financial market volatility. Together with Studies 4 and 5, this analysis helps to rule out the possibility that context effects are responsible for the impact of uncertainty on want/should choices. This study also suggests that uncertainty may have a meaningful impact on choices between wants and shoulds in the field.

\section{Data Set}

A novel panel data set was obtained from a North American online grocer serving urban customers. To preserve business confidentiality, company-specific information has been withheld from this document. Customers pay a flat fee to have groceries they order from this online retailer delivered to their homes one or more days after an order is placed, and customers are required to spend a minimum amount on each order. The panel data set contains deidentified information about the orders placed by all of the company's customers (each assigned a unique ID) between January 1, 2005 and December 31, 2005. The online grocer provided details about each order placed and each item in each order during this 12-month period (including the price paid for each item, the category of each item, the order date, the delivery date, and the customer ID involved).

We restrict our analysis in this paper to the subset of grocery orders analyzed by Milkman, Rogers and Bazerman (2010). This data set excludes orders placed more than five days in advance, orders involving the redemption of a coupon (because discount coupons have been shown to affect online grocery spending as well as the distribution of goods in a customer's shopping basket, see Milkman and Beshears (2009)), each customer's first order of the year, 
spending outliers (top 1\%), and outliers in the number of visits made to the grocer's website during an order (top 1\%). The remaining data includes information about over one million grocery orders (an average of 5 to 10 orders per customer). For more details about this data set, see Milkman et al. (2010).

\section{Classifying Groceries}

We rely on the want/should grocery classification scheme developed in Milkman et al. (2010). Participants in an online survey rated the 117 categories of groceries created by the online grocer (e.g. Frozen Vegetables, Cream, Cookies, etc.) on want and should continuums. A single variable was then generated to quantify where on the spectrum from an extreme should to an extreme want each grocery category fell: this variable was the difference between the average should score raters provided and the average want score they provided. See Milkman et al. (2010) for more detail on how this rating system was generated and validated. Following Milkman et al., (2010), we examine spending on the groceries that receive the 10 highest and lowest ratings, which we consider to be extreme should and extreme want groceries respectively. ${ }^{6}$

\section{Capturing Financial Uncertainty}

Financial uncertainty is quantified with the Chicago Board Options Exchange Volatility Index (VIX), a widely-used proxy for the implied volatility of S\&P 500 Index (SPX) options (Blair et al., 2001; Traub et al. 2000; Nikkinen and Sahlström, 2004). The VIX is "estimates expected volatility by averaging the weighted prices of SPX puts and calls over a wide range of strike prices" (The CBOE Volatility Index - VIX, 2009). The VIX ranged from 10.23 to 17.74

\footnotetext{
${ }^{6}$ The 10 most extreme should grocery categories are: oral hygiene, first aid, vegetables (frozen), produce-fruits, vegetables, feminine care, milk, household cleaners and laundry care. The 10 most extreme want grocery categories are: cookies, wine/wine coolers, ice cream, candy and gum, cigars and tobacco, mixers/bar needs, frozen pizza, cigarettes, spirits, and prepared cocktails.
} 
$($ mean $=12.81 ;$ standard deviation $=1.47)$ during the time period studied. The VIX is only traded when stock markets are open. We therefore restrict our analysis of grocery orders to dates when the VIX closing value could be observed. This reduces the number of grocery orders in our data set from over 1 million to over 750,000 .

\section{Analysis Strategy, Results and Discussion}

We examine the relationship between the VIX closing value on the day of a given customer's grocery order and that customer's spending on extreme want groceries and extreme should groceries. Using an ordinary least squares (OLS) regression, we estimate the relationship between the VIX value and two outcome variables: spending on the 10 most extreme categories of want groceries (average $=\$ 7.37$; standard deviation $=\$ 11.38)$ and spending on the 10 most extreme categories of should groceries (average $=\$ 21.76$; standard deviation $=\$ 16.63$ ). The primary predictor variable in these analyses is the VIX close on the day the order was completed, and the following explanatory variables are included as controls (following Milkman et al., 2010): the number of days in advance of delivery a customer completed her order, the number of times the customer visited the online grocer's website in the course of placing an order, the number of days between the first and last visit the customer made to the grocer's website in the course of placing an order, the number of days since the customer last received a grocery delivery, a dummy indicating if 60 or more days have passed since the customer's last grocery order, the number of orders placed by the customer year to date, dummies for the day of the week when the order was placed, dummies for the day of the week when the order was delivered, and customer fixed effects. Standard errors are clustered at the customer level. ${ }^{7}$

\footnotetext{
${ }^{7}$ As a robustness check, standard errors are clustered at the day level, which reduces the statistical significance of the effect of the VIX on spending on want groceries but has no meaningful impact on the estimated significance of the effect of the VIX on spending on should groceries.
} 
Including customer fixed effects allows us to identify off of within-customer variation in our analyses of the effect of stock market volatility on spending decisions (Wooldridge 2002). Thus, the regression results presented in Table 2 demonstrate how customers' orders differ when the VIX varies, controlling for the average decisions made by a given customer.

Table 2 shows that increases in the VIX, our proxy for uncertainty, are significantly correlated with increased spending on want groceries and decreased spending on should groceries, as predicted by the dual selves model of want/should conflict. While the effect sizes detected are small, given that only a tiny fraction of online grocery customers are likely attentive to uncertainty surrounding stock market performance on any given day, this is not surprising. These findings are correlational in nature and therefore should be interpreted with care, but they do suggest that uncertainty may have meaningful effects on consumer behavior in field settings. 
Table 2. Columns (1) and (2) report OLS coefficients from regressions of customer spending on categories of groceries on the VIX at the close of the day when the order was completed, controlling for the other variables listed. Robust standard errors clustered at the customer level are in parentheses.

\begin{tabular}{|c|c|c|}
\hline & \multicolumn{2}{|c|}{ Dollar Spending on: } \\
\hline & $\begin{array}{l}10 \text { Most Extreme } \\
\text { Wants } \\
\text { (1) }\end{array}$ & $\begin{array}{l}10 \text { Most Extreme } \\
\text { Shoulds } \\
\text { (2) }\end{array}$ \\
\hline \multirow[t]{2}{*}{ Closing VIX on the Day the Order was Completed } & $0.0326^{\star \star \star}$ & $-0.1049^{\star \star \star}$ \\
\hline & $(0.0080)$ & $(0.0104)$ \\
\hline \multirow[t]{2}{*}{ One Day btw Order Completion and Delivery } & -0.0739 & $0.4962^{\star * *}$ \\
\hline & $(0.0510)$ & $(0.0796)$ \\
\hline \multirow[t]{2}{*}{ Days btw Order Completion and Delivery } & $-0.1730^{\star \star *}$ & -0.0623 \\
\hline & $(0.0321)$ & $(0.0575)$ \\
\hline \multirow[t]{2}{*}{ Number of Web Visits for Order } & $0.1543^{\star \star \star}$ & $0.4092^{\star \star *}$ \\
\hline & $(0.0071)$ & $(0.0092)$ \\
\hline \multirow[t]{2}{*}{ Days btw First and Last Web Visits for Order } & $-0.0043^{\star \star \star}$ & $-0.0206^{\star \star \star}$ \\
\hline & $(0.0009)$ & $(0.0015)$ \\
\hline \multirow[t]{2}{*}{ Days Since Last Delivery } & $0.0062^{\star \star *}$ & $0.0362^{\star \star *}$ \\
\hline & $(0.0011)$ & $(0.0015)$ \\
\hline \multirow[t]{2}{*}{60 or More Days Since Last Order } & $-0.5435^{\star \star \star}$ & $-1.5740^{\star * *}$ \\
\hline & $(0.0950)$ & $(0.1298)$ \\
\hline \multirow[t]{2}{*}{ Days Since First Order with Grocer } & $0.0009^{\star * *}$ & $-0.0011^{\star *}$ \\
\hline & $(0.0004)$ & $(0.0005)$ \\
\hline \multirow[t]{2}{*}{ Orders Year to Date } & 0.0058 & $0.0109^{\star}$ \\
\hline & $(0.0045)$ & $(0.0062)$ \\
\hline Day of the Week Order Placed Fixed Effects & Yes & Yes \\
\hline Day of the Week Order Delivered Fixed Effects & Yes & Yes \\
\hline Customer Fixed Effects & Yes & Yes \\
\hline Observations & $750,000+$ & $750,000+$ \\
\hline Customers & $100,000+$ & $100,000+$ \\
\hline Overall $\mathbf{R}^{2}$ & 0.5731 & 0.6262 \\
\hline
\end{tabular}

\section{GENERAL DISCUSSION}

The results presented above suggest that uncertainty can have dramatic effects on choice, contradicting the "sure-thing principle" of Expected Utility Theory (Savage 1954). Specifically, they demonstrate that individuals are more likely to select want options when they face uncertainty about the future or when uncertainty's salience is heightened, suggesting that eliminating uncertainty from situations involving decision making may have meaningful "halo effects". In addition, the increase in want selections driven by uncertainty appears to be most 
extreme when individuals face uncertainty about similar outcomes, whose likeness presumably reduces the ease with which a decision maker can evaluate the possibilities she faces.

The results presented in this paper are consistent with the predictions of the dual systems theory of want/should conflict, which proposes that factors in the environment that make it more difficult to call upon the cognitive should self to reason through choices will increase take-up of wants. However, these results contradict previous research arguing that self-control dilemmas and want/should conflict can be explained by Construal Level Theory (CLT). Research on CLT has associated situational factors that lead to higher-level, abstract construal of a choice with increased take-up of shoulds as well as demonstrating that uncertain situations lead individuals to construe choices at a higher-level. Thus, CLT incorrectly predicts that uncertainty will increase take-up of shoulds.

In addition to their theoretical implications, the findings presented in this paper have implications for a widely used preference elicitation method in experimental economics and psychology. The Becker-Degroot-Marshack (BDM) method for eliciting willingness to pay through an incentive-compatible procedure assumes that making multiple choices without knowing for certain which will be enacted does not alter the nature of those choices. However, Study 4 demonstrates the fallibility of this assumption - when it is uncertain which choice will be enacted, the appeal of wants over shoulds is heightened. This finding has implications for the interpretation of research relying on the BDM method.

These findings also have important policy implications. Research suggesting ways in which people may be "nudged" (Thaler and Sunstein, 2008) to make more should decisions can help policy makers design interventions that will help individuals save more for retirement, exercise more regularly, eat more healthfully, and generally engage in fewer behaviors that are 
costly to society. This paper documents a previously unknown lever - uncertainty - that leads to systematic changes in whether people select shoulds or wants. By removing external uncertainty from decision contexts where the exertion of self-control would be desirable, policy makers may be able to increase the rate at which individuals engage in healthy behaviors.

Individuals can also benefit from the knowledge that uncertainty reduces their capacity to engage in should behaviors. When dieting, saving, or attempting to meet a deadline at work, individuals may benefit from knowing that decreasing other sources of uncertainty in their lives could increase their overall ability to exert self-control. Similarly, managers should be aware of the positive externalities of reducing uncertainty for their employees. By providing clear information about upcoming projects, meetings and events, rather than leaving such things up in the air, managers may be able to increase the rate at which their employees engage in should behaviors like working efficiently rather than procrastinating.

The findings presented here suggest multiple interesting potential avenues for future research. For instance, past research has suggested that unethical decision making may be a want choice (see Mead, Baumeister, Gino, Schweitzer, and Ariely, 2009; Tenbrunsel, Diekmann, Wade-Benzoni, and Bazerman, in press), suggesting that the presence uncertainty may reduce ethical decision making. Future studies could test this intriguing hypothesis. Another possibility raised by this research is that more complex choices may increase the take-up of want options. Past research on choice overload suggests that complex choices reduce individuals' willingness to make purchases (Iyengar and Lepper, 2000) just as uncertainty has previously been shown to reduce people's willingness to make active decisions (Tversky and Shafir, 1992). Future research could examine whether choice overload leads to increased take-up of want options over should options. 


\section{REFERENCES}

Ainslie, G., \& Haendel, V. (1983). The motives of the will. In E. Gottheil, K. A. Druley, T. E. Skoloda, \& H. M. Waxman (Eds.), Etiologic aspects of alcohol and drug abuse (pp. 119140). Springfield, IL: Charles C Thomas.

Baumeister, R. F., Bratslavsky, E., Muraven, M., \& Tice, D. M. (1998). Ego depletion: Is the active self a limited resource? Journal of Personality and Social Psychology, 74, 12521265.

Bazerman, M., Loewenstein, G. \& White, S.B. (1992). Reversals of preference in interpersonal decision making: The difference between judging an alternative and choosing between multiple alternatives Administrative Science Quarterly, 37, 220-240.

Bazerman, M.H., Moore, D.A., Tenbrunsel, A.E., Wade-Benzoni, K.A., \& Blount, S. (1999). Explaining how preferences change across joint versus separate evaluation Journal of Economic Behavior and Organization, 39, 41-58.

Bazerman. M. H., Schroth, H., Pradhan, P., Diekmann, K., \& Tenbrunsel. A. (1994). The inconsistent role of comparison others and procedural justice in reactions to hypothetical job descriptions: Implications for job acceptance decisions Organizational Behavior and Human Decision Processes, 60, 326-352.

Bazerman, M. H., Tenbrunsel, A. E., \& Wade-Benzoni, K. (1998). Negotiating with yourself and losing: Making decisions with competing internal preferences Academy of Management Review, 23(2), 225-241.

Benzion, U., Rapoport, A., \& Yagil, J. (1989). Discount rates inferred from decisions: An experimental study Management Science, 35(3), 270-284. 
Blair, B.J., Poon, S., \& Taylor, S.J. (2001). Forecasting S\&P 100 volatility: the incremental information content of implied volatilities and high-frequency index returns Journal of Econometrics, 105, 5-26.

“The CBOE Volatility Index - VIX" (2009). White Paper http://www.cboe.com/micro/vix/vixwhite.pdf

Dunn, J.R. \& Schweitzer, M.E. (2005). Feeling and believing: The influence of emotion on trust. Journal of Personality and Social Psychology, 88(5), 736-748.

Fujita, K., Trope, Y., Liberman, N. \& Levin-Sagi, M. (2006). Construal levels and self-control. Journal of Personality and Social Psychology 90(3), 351-367.

Haughney, C. (2009). When economy sours, tootsie rolls soothe souls The New York Times Online, March 23, 2009, Accessed Online at

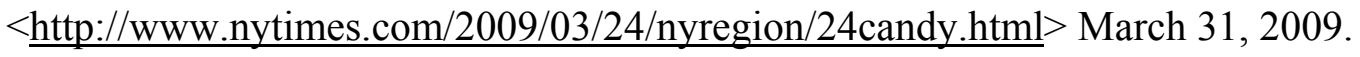

Irwin, J. R., Slovic, P., Lichtenstein, S., \& McClelland, G. 1993. Preference reversals and the measurement of environmental values Journal of Risk and Uncertainty, 6(1), 5-18.

Iyengar, S.S., \& Lepper, M.R. (2000). When choice is demotivating: Can one desire too much of a good thing? Journal of Personality and Social Psychology, 79(6), 995-1006.

Kahneman, D., \& Ritov, I. (1994). Determinants of stated willingness to pay for public goods: A study in the headline method Journal of Risk and Uncertainty, 9: 5-38.

Keltner, D., Locke, K. D., \& Audrain, P. (1993). The influence of attributions on the relevance of negative feelings to personal satisfaction. Personality and Social Psychology Bulletin, $19,21-29$.

Khan, U., \& Dhar, R. (2006). The licensing effect in consumer choice. Journal of Marketing Research 43(2), $259-266$. 
Khan, U \& Dhar, R (2007). Where there is a way, is there a will? The effect of future choices on current preferences. Journal of Experimental Psychology - General 136(2), 277 - 288.

Khan, U., Dhar, R. \& Wertenbroch, K. (2005). A behavioral decision theory perspective on hedonic and utilitarian choice. In S. Ratneshwar, D.G. Mick, (Eds.), Inside consumption: Frontiers of research on consumer motives, goals and desires (pp. 144-165). London: Routledge.

King, G.R. \& Logue, A.W. (1987). Choice in a self-control paradigm with human subjects: effects of changeover delay duration. Learning and Motivation, 18, 421-438.

Kirby, K. N. (1997). Bidding on the future: Evidence against normative discounting of delayed rewards, Journal of Experimental Psychology, 126, 54 - 70.

Kirby, K.N. \& Herrnstein, R.J. (1995). Preference reversals due to myopic discounting of delayed rewards, Psychological Science, 6(2), $83-89$.

Kirby, K.N. \& Marakovic, N.N. (1996). Delayed-discounting probabilistic rewards rates decrease as amounts increase, Psychonomic Bulletin and Review, 3(1), 100 - 104.

Kivetz, Y. \& Tyler, T.R. (2007). Tomorrow I'll be me: The effect of time perspective on the activation of idealistic versus pragmatic selves Organizational Behavior and Human Decision Processes, 102, 193-211.

Lerner, J. S., \& Keltner, D. (2001). Fear, anger, and risk. Journal of Personality and Social Psychology, 81, 146-159.

Loewenstein, G. (1996). Out of control: Visceral influences on behavior Organizational Behavior and Human Decision Processes, 65(3), 272 - 292.

Loomes, G. \& Sugden, R. (1982). Regret theory: An alternative theory of rational choice under uncertainty Economic Journal, 92, 805-824. 
Mas-Colell, A,.Whinston, M.D., \& Green, J.R. (1995). Microeconomic theory. New York, NY: Oxford University Press.

McClure, S.M., Laibson, D., Loewenstein, G., \& Cohen, J.D. (2004). Separate neural systems value immediate and delayed monetary rewards Science, 306, 503-507.

Mead, N., Baumeister, R., Gino, F., Schweitzer, M., \& Ariely, D. (2009). Too tired to tell the truth: Self-control resource depletion and dishonesty. Journal of Experimental Social Psychology, 45(3), 594-597.

Metcalfe, J. \& Mischel, W. (1999). A hot/cool-system analysis of delay of gratification: Dynamics of willpower Psychological Review, 106(1), 3-19.

Milkman, K.L., \& Beshears, J. (2009). Mental accounting and small windfalls: Evidence from an online grocer Journal of Economic Behavior and Organization, 71, 384-394.

Milkman, K.L., Rogers, T. \& Bazerman, M. (2008). Harnessing our inner angels and demons: What we have learned about want/should conflicts and how that knowledge can help us reduce short-sighted decision making Perspectives on Psychological Science, 3, 324338.

Milkman, K.L., Rogers, T. \& Bazerman, M. (2009). Highbrow films gather dust: Timeinconsistent preferences and online DVD rentals Management Science, 55(6), 10471059.

Milkman, K.L., Rogers, T. \& Bazerman, M. (2010). I'll have the ice cream soon and the vegetables later: A study of online grocery purchases and order lead time Marketing Letters, 21(1), 17-36.

Muraven, M. \& Baumeister, R. (2000). Self-regulation and depletion of limited resources: Does self-control resemble a muscle? Psychological Bulletin, 126(2), 247-259. 
Muraven, M., Tice, D. M., \& Baumeister, R. F. (1998). Self-control as limited resource: Regulatory depletion patterns Journal of Personality and Social Psychology, 74, 774789.

Nikkinen, J. \& Sahlström, P. (2004). International transmission of uncertainty implicit in stock index option prices Global Finance Journal, 15(1), 1-15.

Novemsky, N., Dhar, R., Schwarz, N. \& Simonson, I. (2007). Preference fluency in choice Journal of Marketing Research, XLIV, 347-356.

Oster, S., \& Scott Morton, F.M. (2005). Behavioral biases meet the market: The case of magazine subscription prices. Advances in Economic Analysis and Policy, 5.

Read, D. \& van Leeuwen, B. (1998). Predicting hunger: The effects of appetite and delay on choice Organizational Behavior and Human Decision Processes, 76(2), 189-205.

Read, D., Loewenstein, G. \& Kalyanaraman, S. (1999). Mixing virtue and vice: Combining the immediacy effect and the diversification heuristic Journal of Behavioral Decision Making, 12, 257-273.

Rogers, T. \& Bazerman, M.H. (2008). Future lock-in: Future implementation increases selection of 'should' choices Organizational Behavioral and Human Decision Processes, 106(1), $1-20$.

Savage, L.J. (1954). The foundations of statistics. New York, NY: Wiley.

Schelling, T.C. (1984). Choice and consequence: Perspectives of an errant economist. Cambridge, MA: Harvard University Press.

Shafir, E. (1994). Uncertainty and the difficulty of thinking through disjunctions Cognition, 50, $403-430$.

Shafir, E., Simonson, I. \& Tversky, A. (1993). Reason-based choice Cognition, 49, 11 - 36. 
Shafir, E. \& Tversky, A. (1992). Thinking through uncertainty: Nonconsequential reasoning and choice Cognitive Psychology, 24, 449 - 474.

Shiv, B. \& Fedorikhin, A. (1999). Heart and mind in conflict: The interplay of affect and cognition in consumer decision making Journal of Consumer Research, 26(3), 278-292.

Song, H. \& Schwarz, N. (2008). If it's hard to read, it's hard to do Psychological Science, 19(10), 986-988.

Strack, F., Schwarz, N. \& Gschneidinger, E. (1985). Happiness and reminiscing: The role of time perspective, affect, and mode of thinking. Journal of Personality and Social Psychology, 49, 1460-1469.

Tenbrunsel, A.E., Diekmann, K.A., Wade-Benzoni, K.A. \& Bazerman, M.H. (in press). The ethical mirage: A temporal explanation as to why we aren't as ethical as we think we are Research in Organizational Behavior.

Thaler, R.H. (1981). Some empirical evidence on dynamic inconsistency. Economic Letters, 8, 201-207.

Thaler, R.H. \& Shefrin, H.M. (1981). An economic theory of self-control Journal of Political Economy, 89, 392-406.

Thaler, R. H., \& Sunstein, C. R. (2008). Nudge. New Haven, CT: Yale University Press.

Tiedens, L. Z., \& Linton, S. (2001). Judgment under emotional certainty and uncertainty: The effects of specific emotions on information processing. Journal of Personality and Social Psychology, 81, 973-988.

Traub, H.D., Ferreira, L., McArdle, M. \& Antognelli, M. (2000). Fear and greed in global asset allocation. The Journal of Investing, 9(1), 27-31.

Trope, Y. \& Liberman, N. (2003). Temporal construal Psychological Review, 110(3), 403-421. 
Trope, Y., Liberman, N. \& Wakslak, C. (2007). Construal levels and psychological distance: Effects on representation, prediction, evaluation, and behavior Journal of Consumer Psychology, 17(2), 83-95.

Tversky, A. \& Shafir, E. (1992). The disjunction effect in choice under uncertainty Psychological Science, 3(5), 305-309.

Van Den Bos, K. (2001). Uncertainty management: The influence of uncertainty salience on reactions to perceived procedural fairness. Journal of Personality and Social Psychology, 80(6), 931-941.

Van Dijk, E., \& Zeelenberg, M. (2006). The dampening effect of uncertainty on positive and negative emotions Journal of Behavioral Decision Making, 19, 171-176.

Wakslak, C. J., Trope, Y., Liberman, N., \& Alony, R. (2006). Seeing the forest when entry is unlikely: Probability and the mental representation of events Journal of Experimental Psychology: General, 135, 641-653.

Watson, D., Clark, L.A., \& Tellegen, A. (1988). Development and validation of brief measures of positive and negative affect: The PANAS scales Journal of Personality and Social Psychology, 54(6), 1063-1070. 


\section{Appendix A}

Your roommate is worried that you haven't been dating lately and that you're in a romantic slump. As a result, your roommate has insisted on setting you up on a blind date for tonight. You know there are two possible candidates for this date - two of your roommate's colleagues who have both expressed an interest in you. Who you go out with depends on which of these people draws the short straw and has to work overtime tonight - the chances are $50 \%$ that one of them will end up working late and be unable to go out with you and $50 \%$ that it will be the other one. Your roommate has sent you the following profiles of her two co-workers:

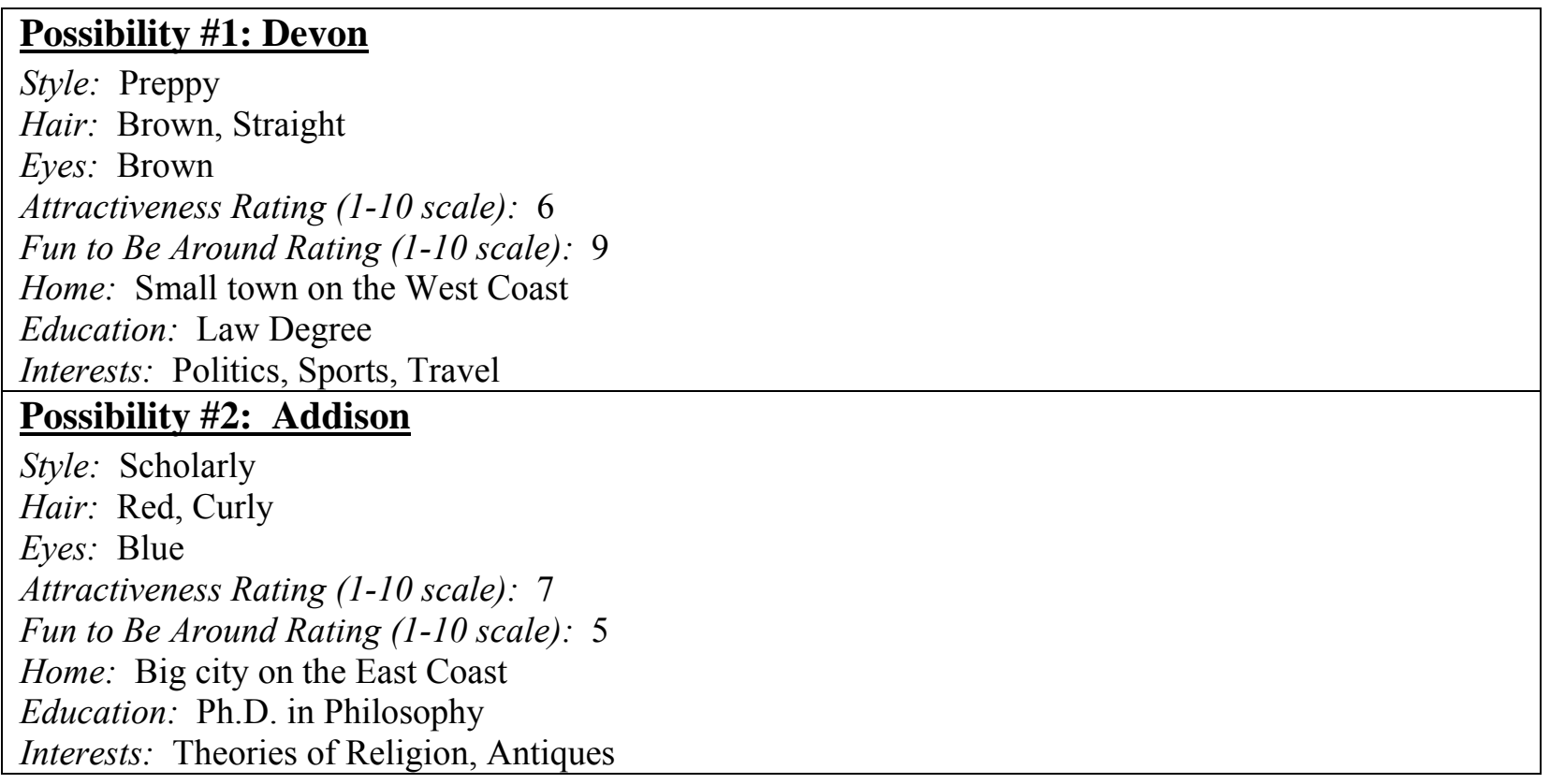

You are in charge of choosing the film for the evening, and your roommate has told you that either of the movies you are considering will appeal to both co-workers. The options are a documentary about a fairly esoteric topic that has been called "a bit dull but highly educational and enlightening" or an action film with attractive movie stars that has been called "empty but highly entertaining". You feel conflicted because you think you should see the documentary but you really want to see the action film. Your roommate is going to buy the movie tickets since the theater is right by her office and she wants to make sure they don't sell out before you arrive. She will give them to her co-worker, who you will meet at the theater tonight.

Devon Condition: \{You find out that preppy Devon will be your date tonight. Addison Condition: \{You find out that scholarly Addison will be your date tonight. Uncertainty Condition: \{Although you are unsure of which of your roommate's co-workers you will spend the evening with, realizing there is a $50 \%$ chance that you will go out with preppy Devon and a $50 \%$ chance that you will go out with scholarly Addison, your roommate has asked you to tell her which movie tickets to buy for your upcoming date.\}

Devon and Addison Conditions: \{Your roommate wants to know what movie you want tickets to see?\} Uncertainty Condition: \{Which movie do you tell her, still unsure of who your date will be, that she should buy tickets for?\} [CIRCLE YOUR CHOICE BELOW]
(a) the documentary
or
(b) the action film 


\section{Appendix B}

You have a big meeting today so your roommate has volunteered to pick up take-out pizza from your favorite pizza place for dinner tonight. Your favorite pizza place only makes one type of pizza each night, and it's always excellent. You've learned from experience that there is a 50\% on Tuesdays (today is a Tuesday) that the available pizza will be a Carne Asada Pizza (see below for a detailed description) and a 50\% chance that it will be a Pesto Chicken Pizza (see below for a detailed description).

\begin{tabular}{|l|l|}
\hline & $\begin{array}{l}\text { Possibility \#1: Carne Asada Pizza } \\
\text { Grilled steak, fire-roasted mild chilies, } \\
\text { onions, cilantro pesto, Monterey Jack, } \\
\text { and Mozzarella cheeses. Topped with } \\
\text { fresh tomato salsa and cilantro. Served } \\
\text { with a side of tomatillo salsa. }\end{array}$ \\
\hline & $\begin{array}{l}\text { Possibility \#2: Pesto Chicken Pizza } \\
\text { NEAPOLITAN PIZZA: Grilled chicken } \\
\text { breast marinated in a basil pesto sauce } \\
\text { with mild onions, Mozzarella cheese, } \\
\text { sun-dried tomatoes, pesto sauce and } \\
\text { toasted pine nuts. }\end{array}$ \\
\hline
\end{tabular}

Carne Asada Condition: \{This morning your roommate called the restaurant and learned that the pizza available tonight would be Carne Asada Pizza.\}

Pesto Chicken Condition: \{This morning your roommate called the restaurant and learned that the pizza available tonight would be Pesto Chicken Pizza.\}

Uncertainty Condition: \{Tonight when you get home, you will find out which pizza you are eating Carne Asada Pizza or Pesto Chicken Pizza.\}

You are in charge of choosing what dessert to have with the pizza for dinner: (a) fresh fruit salad or (b) fresh brownies. You are trying to lose weight, so you know you probably should choose the fresh fruit salad, but fresh brownies are what you viscerally want.

Carne Asada Condition: \{Your roommate has asked you to tell her which to buy for dessert after your Carne Asada Pizza dinner?\}

Pesto Chicken Condition: \{Your roommate has asked you to tell her which to buy for dessert after your Pesto Chicken Pizza dinner?\}

Uncertainty Condition: $\{$ Although you are unsure of which pizza you will be eating tonight, realizing there is a 50\% chance that you will have Carne Asada Pizza and a 50\% chance that you will have Pesto Chicken Pizza, your roommate has asked you to tell her which dessert to buy for tonight?

Which do you tell her, still unsure of the pizza you will be eating, that she should buy for dessert?\} [CIRCLE YOUR CHOICE BELOW]
(a) fresh fruit salad
or
(b) fresh brownies 


\section{Appendix C}

SCREEN 1 - All Conditions (following a prompt for the participant's ID)

Please do your best to memorize this number: 6718649052 .

SCREEN 2 - Uncertainty Condition

Tomorrow a coin flip will determine which of the following web radio stations you listen to for 15 minutes while you are in the behavioral lab.

(1) Oldies Music Web Radio

or

(2) Pop Music Web Radio

SCREEN 2 - Certainty Condition 1 (Pop)

Tomorrow it has been determined that you will listen to the following web radio station for 15 minutes while you are in the behavioral lab.

\section{Pop Music Web Radio}

SCREEN 2 - Certainty Condition 2 (Oldies)

Tomorrow it has been determined that you will listen to the following web radio station for 15 minutes while you are in the behavioral lab. 
SCREEN 3 - Uncertainty Condition

Now you need to make the following choice, which we will hold you to tomorrow:

\section{Note that this choice is not hypothetical - it is a real choice!}

Tomorrow you will read an article during the 15 minutes you spend listening to the radio station determined by a coin flip: either Oldies Music Web Radio or Pop Music Web Radio.

Those 15 minutes will be spent reading either: (a) a magazine article about a fairly esoteric topic that has been called "a bit dull but highly educational and enlightening" or (b) an article about a popular topic that has been called "empty but highly entertaining".

Now you must choose which article you want to read while you listen to the radio station determined by a coin flip:

An article about a popular topic that has been called "empty but highly entertaining"

An article about an esoteric topic that has been called "a bit dull but highly educational and enlightening"

SCREEN 3 - Certainty Condition 2 (Pop)

Now you need to make the following choice, which we will hold you to tomorrow:

\section{Note that this choice is not hypothetical - it is a real choice!}

Tomorrow you will read an article during the 15 minutes you spend listening to the radio station: Pop Music Web Radio.

Those 15 minutes will be spent reading either: (a) a magazine article about a fairly esoteric topic that has been called "a bit dull but highly educational and enlightening" or (b) an article about a popular topic that has been called "empty but highly entertaining".

Now you must choose which article you want to read while you listen to the radio station listed above:

An article about an esoteric topic that has been called "a bit dull but highly educational and enlightening"

An article about a popular topic that has been called "empty but highly entertaining" 
SCREEN 3 - Certainty Condition 2 (Oldies)

\section{Now you need to make the following choice, which we will hold you to tomorrow:}

Note that this choice is not hypothetical - it is a real choice!

Tomorrow you will read an article during the 15 minutes you spend listening to the radio station: Oldies Music Web Radio.

Those 15 minutes will be spent reading either: (a) a magazine article about a fairly esoteric topic that has been called "a bit dull but highly educational and enlightening" or (b) an article about a popular topic that has been called "empty but highly entertaining".

Now you must choose which article you want to read while you listen to the radio station listed above:

An article about a popular topic that has been called "empty but highly entertaining"

An article about an esoteric topic that has been called "a bit dull but highly educational and enlightening"

\section{SCREEN 4 - All Conditions}

To the best of your ability, please attempt to remember the number you were asked to memorize at the beginning of this survey:

\section{SCREEN 5 - All Conditions}

Please rate how cognitively taxing it was for you to make a choice about what article to read tomorrow for 15 minutes while listening to web radio:

1 - not at all cognitively taxing O

\section{3}

0
7 - extremely cognitively taxing 


\section{Appendix D}

\section{Want and Should Definitions Provided to Raters}

A "want" tv show is one that someone would choose to see for the pure enjoyment of it. There may be additional reasons for seeing the tv show - it may be intellectually stimulating or recommended by people the viewer would like to impress, but these reasons are not to be taken into account when determining the "want" score of the tv show. The "want" score is intended to reflect the extent to which someone's decision to watch this tv show would be indulgent and pleasure-based.

Example of a strong "want" tv show: A blockbuster, featuring attractive movie stars, with an appealing advertising campaign.

A "should" tv show is one that someone would feel he/she should watch. This might be because the tv show is expected to improve the viewer in some way - intellectually, socially (because of recommendations from people the viewer would like to impress), or otherwise. The "should" score ought to reflect the extent to which someone's choice to watch the tv show would be made for virtuous, self-improving reasons, regardless of other potential factors.

Example of a strong "should" tv show: A tv show that audiences feel compelled to watch for their betterment as human beings - in other words, for reasons besides sheer pleasure.

Please note that "want" and "should" tv shows are not mutually exclusive - a tv show may receive both a high "want" score and a high "should" score.

Show Titles, Descriptions, and Bins Based on SMW Scores

\begin{tabular}{|l|l|c|}
\hline $\begin{array}{l}\text { Show } \\
\text { Title }\end{array}$ & Description & Bin $^{8}$ \\
\hline & $\begin{array}{l}\text { Lipstick Jungle is another hit novel by Sex and the City author Candace Bushnell. } \\
\text { While Sex and the City followed the exploits of four single women looking for love } \\
\text { in New York, Lipstick Jungle tracks three powerful career women who are willing to } \\
\text { do almost anything for success in the business world: Wendy Healy (Brooke Shields), } \\
\text { president of Parador Pictures, Victory Ford (Lindsay Price), a high profile fashion } \\
\text { designer, and Nico Reilly (Kim Raver), editor-in-chief of a hot selling fashion } \\
\text { magazine named Bonfire Magazine. }\end{array}$ & \\
$\begin{array}{l}\text { Lipstick } \\
\text { Jungle }\end{array}$ & $\begin{array}{l}\text { Former police detective Adrian Monk (Tony Shalhoub), whose photographic memory } \\
\text { and amazing ability to piece together tiny clues made him a local legend, has suffered } \\
\text { from intensified obsessive-compulsive disorder and a variety of phobias since the } \\
\text { unsolved murder of his wife, Trudy, in 1997. Now on psychiatric leave from the San }\end{array}$ & \\
\hline Francisco Police Department and working as a freelance... & \\
Monk & $\begin{array}{l}\text { Edward Albright is a super spy. Henry Spivey is living the normal American dream in } \\
\text { the suburbs with his wife, two kids and dog. The two men have one thing in common } \\
\text { - they share the same body because Edward took part in an experiment several years }\end{array}$ & \\
\hline $\begin{array}{l}\text { My Own } \\
\text { Worst } \\
\text { Enemy }\end{array}$ & 1 \\
\hline
\end{tabular}

\footnotetext{
${ }^{8}$ Bin $1=$ extreme wants, Bin $6=$ extreme shoulds
} 


\begin{tabular}{|c|c|c|}
\hline & $\begin{array}{l}\text { earlier to create a split personality. Henry has never met his alter-ego Edward, except } \\
\text { for an email he receives from Edward saying that people are coming to kill him. Now, } \\
\text { the super spy and the suburban daddy have to learn to live with each other in the same } \\
\text { body and not get each other killed. }\end{array}$ & \\
\hline The O.C. & $\begin{array}{l}\text { The O.C. - also known as Orange County, California - is an idyllic paradise, a } \\
\text { wealthy, harbor-front community where everything and everyone appears to be } \\
\text { perfect. But beneath the surface is a world of shifting loyalties and identities, of kids } \\
\text { living secret lives hidden from their parents and of parents living secret lives hidden } \\
\text { from their children. 'The O.C.' tells the story of the Cohen, Cooper and Nichol } \\
\text { families and Ryan Atwood, a troubled teen from the wrong side of the tracks who is } \\
\text { thrust into this world and who will forever change the lives of the residents of The } \\
\text { O.C. }\end{array}$ & 1 \\
\hline $\begin{array}{l}\text { Party of } \\
\text { Five }\end{array}$ & $\begin{array}{l}\text { Nothing could be worse than the sudden death of parents. One day Nick and Diana } \\
\text { Salinger were killed in a terrible car crash, and left their five children all alone. } \\
\text { Together, they go through all sorts of problems, from handling their parents } \\
\text { restaurant and trying to keep it running to disastrous relationships and school } \\
\text { problems. Soon they realize that in order to survive, no one can be selfish and they all } \\
\text { have to help each other. They're a family and have to stick together. }\end{array}$ & 1 \\
\hline $\begin{array}{l}\text { Prison } \\
\text { Break }\end{array}$ & $\begin{array}{l}\text { After getting himself incarcerated in Fox River State Penitentiary to free his wrongly } \\
\text { accused brother, Lincoln Burrows, Michael Scofield is now on the loose-along with } \\
\text { his brother. Tasked by a government agent to take down The Company, the brothers } \\
\text { work along side former correctional officer Brad Bellick, former federal agent } \\
\text { Alexander Mahone and other odd characters. }\end{array}$ & 1 \\
\hline Psych & $\begin{array}{l}\text { Fake Psychic. Real Detectives. Shawn Spencer has developed a keen eye for detail } \\
\text { after being instructed by his police officer father to note even the most minute details } \\
\text { of his surroundings. After conning the police into believing that he's a psychic, } \\
\text { Shawn opens a detective agency with best friend Burton Guster. }\end{array}$ & 1 \\
\hline $\begin{array}{l}\text { Studio } 60 \\
\text { on the } \\
\text { Sunset } \\
\text { Strip }\end{array}$ & $\begin{array}{l}\text { Look behind the scenes of Studio 60, a fictional sketch-comedy series on the NBS } \\
\text { broadcast network. Problem is the series seems to be going down the tube fast. } \\
\text { Everyone involved with the late-night dud seems to have one problem or another, } \\
\text { including the current Executive Producer, who just had an on-air mental meltdown, } \\
\text { and time is running out fast. Enter the network's Chairman of the Board (Steven } \\
\text { Weber) and a new network president (Amanda Peet) looking to make her mark on the } \\
\text { net. Her answer is move is to bring in a pair of fresh-faced writers (Matthew Perry } \\
\text { and Bradley Whitford) to try and save the series. Will it work? }\end{array}$ & 1 \\
\hline $\begin{array}{l}\text { Terminator } \\
\text { : The Sarah } \\
\text { Conner } \\
\text { Chronicles }\end{array}$ & $\begin{array}{l}\text { After two years in one place Sarah decides they need a change of scenery and in } \\
\text { doing so they expose themselves to FBI Agent James Ellison (Richard T. Jones) and } \\
\text { Skynet's army of Terminators including Cameron Phillips (Summer Glau) a } \\
\text { reprogrammed Terminator sent to protect John. She informs them that Judgment Day } \\
\text { was not stopped and will take place in } 2011 \text {. John convinces Sarah to stop hiding and } \\
\text { fight so Cameron takes them to a time machine the resistance has set up to take them } \\
\text { to the year Skynet was created } 2007 \text {. }\end{array}$ & 1 \\
\hline Angel & $\begin{array}{l}\text { Joss Whedon, the creator and executive producer of the international hit series Buffy } \\
\text { the Vampire Slayer, combines supernatural adventure and dark humor in this next } \\
\text { chapter of the Buffy mythology. Just as Whedon and executive producer David } \\
\text { Greenwalt brought the monsters of adolescence to life with Buffy, this one-hour } \\
\text { series explores the twists and turns of early adulthood with the same irony and wit. A } \\
\text { centuries-old vampire cursed with a conscience, Angel left the small California town } \\
\text { of Sunnydale and the only woman he ever loved to take up residence in Los Angeles, } \\
\text { the City of Angels. Between pervasive evil and countless temptations lurking beneath } \\
\text { the city's glittery facade, L.A. has proven to be the ideal address for a fallen vampire } \\
\text { looking to save a few lost souls and, in turn, perhaps redeem his own. }\end{array}$ & \\
\hline $\begin{array}{l}\text { Buffy The } \\
\text { Vampire }\end{array}$ & $\begin{array}{l}\text { Buffy the Vampire Slayer is a comedy-action series that chronicles the adventures of } \\
\text { Buffy Summers, a teenage girl who is gifted with the strength and skill to hunt }\end{array}$ & \\
\hline
\end{tabular}




\begin{tabular}{|c|c|c|}
\hline & & \\
\hline $\begin{array}{l}\text { Charlie's } \\
\text { Angels }\end{array}$ & $\begin{array}{l}\text { Beautiful, intelligent and ultra-sophisticated, "Charlie's Angels" are everything a man } \\
\text { could dream of...and way more than they could ever handle! Receiving their orders } \\
\text { via speaker phone from their never seen boss, Charlie, the Angels employ their } \\
\text { incomparable sleuthing and combat skills, as well as their lethal feminine charm, to } \\
\text { crack even the most seemingly insurmountable of cases. }\end{array}$ & 1 \\
\hline Chuck & $\begin{array}{l}\text { Action-comedy series about Chuck Bartowski (Zachary Levi, "Less Than Perfect") -- } \\
\text { a computer geek who is catapulted into a new career as the government's most vital } \\
\text { secret agent. When Chuck opens an e-mail subliminally encoded with government } \\
\text { secrets, he unwittingly downloads an entire server of sensitive data into his brain. } \\
\text { Now, the fate of the world lies in the unlikely hands of a guy who works at a Buy } \\
\text { More Electronics store. }\end{array}$ & 1 \\
\hline Fame & $\begin{array}{l}\text { The New York City High School for the Performing Arts was their dream. They } \\
\text { wanted to dance, to sing, to play music, and to act... but above all they want to live } \\
\text { their lives while they are still young and full of energy. }\end{array}$ & 1 \\
\hline Fringe & $\begin{array}{l}\text { When an international flight lands at Boston's Logan Airport and the passengers and } \\
\text { crew have all died grisly deaths, FBI Special Agent OLIVIA DUNHAM (newcomer } \\
\text { Anna Torv) is called in to investigate. After her partner, Special Agent JOHN SCOTT } \\
\text { (Mark Valley, "Boston Legal"), is nearly killed during the investigation, a desperate } \\
\text { Olivia searches frantically for someone to help, leading her to DR. WALTER } \\
\text { BISHOP (John Noble, "Lord of the Rings: Return of the King"), our generation's } \\
\text { Einstein. There's only one catch: he's been institutionalized for the last } 20 \text { years, and } \\
\text { the only way to question him requires pulling his estranged son PETER (Joshua } \\
\text { Jackson, "Dawson's Creek") in to help. When Olivia's investigation leads her to } \\
\text { manipulative corporate executive NINA SHARP (Blair Brown, "Altered States"), our } \\
\text { unlikely trio along with fellow FBI Agents PHILLIP BROYLES (Lance Reddick, } \\
\text { "The Wire"), CHARLIE FRANCIS (Kirk Acevedo, "Oz") and ASTRID } \\
\text { FARNSWORTH (Jasika Nicole, "Law \& Order: Criminal Intent") will discover that } \\
\text { what happened on Flight } 627 \text { is only a small piece of a larger, more shocking truth. }\end{array}$ & 1 \\
\hline Highlander & $\begin{array}{l}\text { Highlander follows one Immortal, Duncan MacLeod of the Clan MacLeod (known as } \\
\text { "The Highlander" to other Immortals). Duncan MacLeod, born } 400 \text { years ago in the } \\
\text { Highlands of Scotland, is on an ongoing quest, since "In the End, There Can Be Only } \\
\text { One." }\end{array}$ & 1 \\
\hline Airwolf & $\begin{array}{l}\text { Created by Donald P. Bellisario, who had already had such hits as 'Magnum p.i.' } \\
\text { (1980-1988), 'Airwolf' followed the adventures of a hi-tech helicopter and it's } \\
\text { reclusive pilot, Stringfellow Hawke. }\end{array}$ & 2 \\
\hline $\begin{array}{l}\text { Journeyma } \\
\mathrm{n}\end{array}$ & $\begin{array}{l}\text { Kevin McKidd (Rome) stars as Dan Vassar in this new series from NBC set to air in } \\
\text { the fall of } 2007 \text {. Dan is happily married with a son. It seems like he has everything } \\
\text { going for him. Dan ends up traveling into the past. He changes people's lives, } \\
\text { sometimes for the better, but sometimes not. During his travels he meets up with } \\
\text { Livia Beale, he was engaged to her when she died in a plane crash. Knowing the } \\
\text { future he has a chance to save her but how will that change his own future? }\end{array}$ & 2 \\
\hline $\begin{array}{l}\text { Late Night } \\
\text { with Conan } \\
\text { O'Brian }\end{array}$ & $\begin{array}{l}\text { Smart-alecky, ribald and whimsical, "Late Night with Conan O'Brien" rose to become } \\
\text { a critical darling and dorm favorite after a rocky start in 1993. A distinct brand of } \\
\text { humor, Late Night employs the use of various recurring characters (including } \\
\text { Triumph the Insult Comic Dog, Vomiting Kermit, Eyeballs O'Shaughnessy, } \\
\text { NASCAR-driving shotgun-toting Jesus, Masturbating Bear) and comedy bits. }\end{array}$ & 2 \\
\hline $\begin{array}{l}\text { Miami } \\
\text { Vice }\end{array}$ & $\begin{array}{l}\text { Miami Vice was one of the most innovative and powerful TV series of all time. } \\
\text { Focusing on the Miami Metro-Dade Police "Vice" Department and it's continued } \\
\text { battle against the illicit drug, prostitution, and firearms crime underworld of the city } \\
\text { of Miami. It used fashion, color, and a varied musical selection in order to accentuate } \\
\text { and amplify the emotional undercurrent of the drama it portrayed. }\end{array}$ & 2 \\
\hline $\begin{array}{l}\text { The } \\
\text { Moment of }\end{array}$ & $\begin{array}{l}\text { Sometimes when asked difficult personal questions, a little lie won't hurt. Unless } \\
\text { you're on the game show The Moment of Truth, and your lie is detected by a lie }\end{array}$ & \\
\hline
\end{tabular}




\begin{tabular}{|c|c|c|}
\hline truth & $\begin{array}{l}\text { detector test. Host Mark L. Walberg administers the questions already answered by } \\
\text { contestants previous to the show's taping. The prize is } \$ 500,000 \text {, but will it be worth } \\
\text { it? }\end{array}$ & \\
\hline $\begin{array}{l}\text { My Bare } \\
\text { Lady }\end{array}$ & $\begin{array}{l}\text { Four American adult film stars are given the chance to do some 'real' acting. After an } \\
\text { extensive LA casting call, four porn stars are selected by a British casting director to } \\
\text { attend a professional acting school in the Garrick Theatre in London. Many adult film } \\
\text { stars feel that they can act as well as any other actor, if they were given a chance. But } \\
\text { will these wanna-be thespians be able to cut.. }\end{array}$ & 2 \\
\hline $\begin{array}{l}\text { One Tree } \\
\text { Hill }\end{array}$ & $\begin{array}{l}\text { Tree Hill follows the lives and loves of these two brothers, their friends and their } \\
\text { family as they navigate high school, marriage, and finally... adulthood. Set in the } \\
\text { small town of Tree Hill, NC, this teen-driven drama tells the story of two half } \\
\text { brothers, who share a last name and nothing else. Brooding blue-collar Lucas is a } \\
\text { talented street-side basketball player, but his skills are appreciated only by his friends } \\
\text { at the river court. Popular, affluent Nathan basks in the hero-worship of the town, as } \\
\text { the star of his high school team. And both boys are the son of former college ball } \\
\text { player, Dan Scott, whose long ago choice to abandon Lucas and his mother Karen, } \\
\text { will haunt him long into his life with wife Deb, and their son Nathan. }\end{array}$ & 2 \\
\hline $\begin{array}{l}\text { The } \\
\text { Pretender }\end{array}$ & $\begin{array}{l}\text { The Pretender is the story of Jarod, a boy-genius taken from his family as a child. } \\
\text { Jarod possesses the ability to quickly learn and impersonate different jobs and } \\
\text { occupations. His abductors, a facility simply known as The Centre, tested his abilities } \\
\text { through various simulations. }\end{array}$ & 2 \\
\hline Raines & $\begin{array}{l}\text { In this drama from NBC Universal Television, LAPD Detective Michael Raines has } \\
\text { the ability to have detailed conversations with deceased crime victims but by only } \\
\text { using his imagination. This unique "talent" allows him to retrace the steps leading up } \\
\text { to their murders and helps him to solve the cases. Although he also must also deal } \\
\text { with the apparition of his dead partner, Raines won't stop until each killer is found } \\
\text { and brought to justice. }\end{array}$ & 2 \\
\hline $\begin{array}{l}\text { The Real } \\
\text { Housewive } \\
\text { s of Atlanta }\end{array}$ & $\begin{array}{l}\text { An up-close and personal look at life in Hotlanta, The Real Housewives of Atlanta } \\
\text { follows five glamorous Southern belles -- DeShawn, Kim, Lisa, NeNe, and Sheree -- } \\
\text { as they balance motherhood, demanding careers and a fast-paced social calendar, and } \\
\text { shows what life is like in the most exclusive areas of Atlanta. These driven and } \\
\text { ambitious women prove that they're not just "housewives," but entrepreneurs, doting } \\
\text { mothers and classy Southern women. }\end{array}$ & 2 \\
\hline $\begin{array}{l}\text { Remington } \\
\text { Steele }\end{array}$ & $\begin{array}{l}\text { Remington Steele is an American television series, produced by MTM Enterprises } \\
\text { and first broadcast on the NBC network from } 1982 \text { to } 1987 \text {. It starred Stephanie } \\
\text { Zimbalist as private detective Laura Holt and Pierce Brosnan as a roguish former } \\
\text { white-collar thief and con man who assumed the fictitious Remington Steele identity. } \\
\text { The show took an offbeat approach to the standard TV detective genre, with ironic } \\
\text { plotting and elements of romantic comedy. }\end{array}$ & 2 \\
\hline Roswell & $\begin{array}{l}\text { Human/Alien hybrids, must hide their alien sides to fit into their New Mexico-high } \\
\text { school, while attempting to learn about their past, their gifts, and love as outsiders. } \\
\text { Their destinies clash with their feelings as they discover the extraordinary } \\
\text { circumstances that led them to Earth, and may eventually lead them home. }\end{array}$ & 2 \\
\hline $\begin{array}{l}\text { Simon \& } \\
\text { Simon }\end{array}$ & $\begin{array}{l}\text { Simon \& Simon is a show based on two brothers who just happen to be private } \\
\text { investigators. They live and work in San Diego where once a week, for eight seasons, } \\
\text { the series revealed the loyality and love they had for one another. "They're more than } \\
\text { brothers, they're best of friends." }\end{array}$ & 2 \\
\hline Solitary & $\begin{array}{l}\text { This new reality competition by FOX pits nine people against each other in the } \\
\text { ultimate battle of endurance. Nine contestants are isolated from the rest of the world - } \\
\text { - and also from each other. The players then become subjects in a series of strange } \\
\text { and taxing experiments. They must endure challenges involving hunger, pain, sleep } \\
\text { deprevation, mind control, and more! All for the coveted } \$ 50,000 \text { prize. Though there } \\
\text { are nine players in this game, the real battle lies between each contestant and his or } \\
\text { her own self. }\end{array}$ & \\
\hline
\end{tabular}




\begin{tabular}{|c|c|c|}
\hline $\begin{array}{l}\text { St. } \\
\text { Elsewhere }\end{array}$ & $\begin{array}{l}\text { St. Eligius Hospital in South Boston was not exactly the world's best health care } \\
\text { center. Despite its flaws, it featured some of the most caring doctors and nurses you } \\
\text { could ever meet. Led by Dr. Donald Westphall (and later by Dr. Benjamin Gideon), } \\
\text { St. Eligius became a sanctuary for the underdog and the downtrodden. }\end{array}$ & 2 \\
\hline $\begin{array}{l}\text { Starsky and } \\
\text { Hutch }\end{array}$ & $\begin{array}{l}\text { On the surface, plain-clothes Detectives Starsky and Hutch are like oil and water. Ken } \\
\text { Hutchinson opts very much for the quiet life, being well read, a deep thinker, and } \\
\text { enjoying fine cuisine. Dave Starsky, on the other hand, is louder, more brash, } \\
\text { enjoying street life and a diet of junk food. Their personalities might contrast, but } \\
\text { once together, they mesh perfectly, practically operating and thinking as one, as they } \\
\text { rid the streets of muggers, drug pushers, murderers, rapists, racketeers, and similar } \\
\text { scum. }\end{array}$ & 2 \\
\hline $\begin{array}{l}\text { The Starter } \\
\text { Wife }\end{array}$ & $\begin{array}{l}\text { The Starter Wife, based on the best-selling novel by Gigi Levangie Grazer, chronicles } \\
\text { the events of one woman's life following her divorce after years of marriage to a } \\
\text { Hollywood studio executive. }\end{array}$ & 2 \\
\hline Sunset Tan & $\begin{array}{l}\text { Despite being remarkably sunny in Los Angeles, not everyone can easily get tan. } \\
\text { That's where Sunset Tan comes in. They are one of the most go-to tanning salons out } \\
\text { there and celebrities agree. Along with this new show, comes a new employee, Erin. } \\
\text { Erin grew up in a small town and isn't exactly sure if the city is where she should be, } \\
\text { because the employees even aren't all that smart... }\end{array}$ & 2 \\
\hline $\begin{array}{l}\text { Temptation } \\
\text { Island }\end{array}$ & $\begin{array}{l}\text { Temptation Island is a reality series in which four unmarried couples travelled to an } \\
\text { exotic location to test the strength of their relationship. When couples arrive to the } \\
\text { exotic location, } 26 \text { singles have been presented to them. When the whole story } \\
\text { finishes they all get back together at bonfire where they decide about the future of } \\
\text { their relationships. }\end{array}$ & 2 \\
\hline $\begin{array}{l}\text { The Time } \\
\text { Tunnel }\end{array}$ & $\begin{array}{l}\text { The Time Tunnel chronicles the adventures of two scientists, Dr. Tony Newman and } \\
\text { Dr. Douglas Phillips. Both are working on Project TicToc, a government operation to } \\
\text { perfect time travel. The two American scientists are lost in the swirling maze of past } \\
\text { and future ages, during the first experiments on America's greatest and most secret } \\
\text { project, the Time Tunnel. }\end{array}$ & 2 \\
\hline Vanished & $\begin{array}{l}\text { This FOX drama centers on the search for Sara Collins. She's the wife of Senator } \\
\text { Jeffrey Collins. Sara vanishes and the FBI lead by Agent Graham Kelton is on the } \\
\text { job, but before they can find her they need to find out who she really is. The search } \\
\text { for Sara will expose many secrets. Nothing is as it seems. Everyone is a suspect } \\
\text { because of their secrets. }\end{array}$ & 2 \\
\hline Bones & $\begin{array}{l}\text { Inspired by the real-life forensic anthropologist and best-selling novelist Kathy } \\
\text { Reichs, Bones is a darkly amusing investigative drama centered on Dr. Temperance } \\
\text { Brennan, a forensic anthropologist who writes novels on the side. She and FBI } \\
\text { Special Agent Seelely Booth take on murder cases that defy the standard methods of } \\
\text { identifying a body, requiring Brennan to use her uncanny ability to read clues in } \\
\text { victims' bones. }\end{array}$ & 2 \\
\hline $\begin{array}{l}\text { Chicago } \\
\text { Hope }\end{array}$ & $\begin{array}{l}\text { "Chicago Hope" focuses on the heroic and eclectic staff of doctors practicing cutting- } \\
\text { edge medicine at Chicago Hope Hospital. In the changing world of modern health } \\
\text { care, the staff members continue to upgrade their medical skills while trying to } \\
\text { maintain a modicum of sanity in the pressure cooker of high-tech medicine. Their } \\
\text { task is complicated by the fact that "Chicago Hope" has developed a reputation for } \\
\text { being "the last, best hope," a place where patients come for treatment that no other } \\
\text { institution can, or dares, to provide. }\end{array}$ & \\
\hline ER & Doctors labor to save lives in the emergency room of a Chicago hospital. & 2 \\
\hline $\begin{array}{l}\text { The Fall } \\
\text { Guy }\end{array}$ & $\begin{array}{l}\text { Colt Seavers is a Hollywood stuntman by trade... but work in Hollywood is } \\
\text { sometimes hard to come by. Fortunately, Colt's other job is as a bounty hunter - and } \\
\text { there's never any shortage of bail-jumping bad guys to hunt down. Colt is helped by } \\
\text { his young and enthusiastic cousin Howie - who knows a little bit about everything } \\
\text { and not enough about anything - and Jody, a stunningly beautiful stuntwoman. The } \\
\text { trio use the tricks of the stunt trade to catch the criminals. }\end{array}$ & \\
\hline
\end{tabular}




\begin{tabular}{|c|c|c|}
\hline $\begin{array}{l}\text { Friday } \\
\text { Night } \\
\text { Lights }\end{array}$ & $\begin{array}{l}\text { A small Texas town has high expectations for its top-ranked football team. Expanding } \\
\text { on the hit feature film "Friday Night Lights," this poignant series centers on the small } \\
\text { rural town of Dillon, Texas, where the coveted state football championship rings are } \\
\text { held in the highest regard. }\end{array}$ & 2 \\
\hline House & $\begin{array}{l}\text { Dr. Gregory House (Hugh Laurie) is devoid of anything resembling bedside manner } \\
\text { and wouldn't even talk to his patients if he could get away with it. Dealing with his } \\
\text { own constant physical pain, he uses a cane that seems to punctuate his acerbic, } \\
\text { brutally honest demeanor. While his behavior can border on antisocial, House is a } \\
\text { brilliant diagnostician whose unconventional thinking and flawless instincts afford } \\
\text { him widespread respect. An infectious disease specialist, House thrives on the } \\
\text { challenge of solving medical puzzles in order to save lives. He has assembled an elite } \\
\text { team of young experts to help him unravel these diagnostic mysteries: neurologist Dr. } \\
\text { Eric Foreman (Omar Epps); immunologist Dr. Allison Cameron (Jennifer Morrison); } \\
\text { and intensevist Dr. Robert Chase (Jesse Spencer). House has a good friend and } \\
\text { confidant in oncology specialist Dr. James Wilson (Robert Sean Leonard), with } \\
\text { whom he consults with on a regular basis. }\end{array}$ & 2 \\
\hline $\begin{array}{l}\text { The A } \\
\text { Team }\end{array}$ & $\begin{array}{l}\text { In } 1972 \text { a crack commando unit was sent to prison by a military court for a crime they } \\
\text { didn't commit. These men promptly escaped from a maximum security stockade to } \\
\text { the Los Angeles underground. Today, still wanted by the government, they survive as } \\
\text { soldiers of fortune. If you have a problem, if no one else can help, and if you can find } \\
\text { them, maybe you can hire: THE A-TEAM. }\end{array}$ & 3 \\
\hline $\begin{array}{l}\text { The } \\
\text { Academy }\end{array}$ & $\begin{array}{l}\text { This new reality series follows a group of Los Angeles police recruits through the } \\
\text { grueling training regimen they all must endure before earning their badges as full- } \\
\text { fledged members of the police force. }\end{array}$ & 3 \\
\hline John Doe & $\begin{array}{l}\text { The series is about the life of John Doe, a mysterious man who rises from the } \\
\text { primordial waters of an isolated island, possessing knowledge of literally everything } \\
\text { in the world, yet having no memory of who -- or even what -- he is. Doe quickly finds } \\
\text { his way to Seattle, where he befriends the police and uses his special gift to help them } \\
\text { solve "impossible" crimes each week, while continuing his unending quest to uncover } \\
\text { who he is and where he came from. In his search to unlock the key to his past, He } \\
\text { may be a government agent, an extra-terrestrial or perhaps just a regular John Doe } \\
\text { with a bout of amnesia. Whatever secrets his past holds, Doe is now the man who } \\
\text { knows everything -- a gift that will forever change his destiny. }\end{array}$ & 3 \\
\hline K-Ville & $\begin{array}{l}\text { It's been two years since Hurricane Katrina ravaged New Orleans and a select few } \\
\text { still remain at the NOPD. These special cops are bound and determined to bring back } \\
\text { the life to New Orleans, otherwise known to most as K-Ville (Katrinaville), and clean } \\
\text { up the crime and damage that still remains }\end{array}$ & 3 \\
\hline $\begin{array}{l}\text { Knight } \\
\text { Rider }\end{array}$ & $\begin{array}{l}\text { The adventures of Michael Knight and his incredible super-car K.I.T.T., Knight } \\
\text { Industries } 2000 \text {. Selected by a dying billionaire, Wilton Knight, Michael works for } \\
\text { the Foundation for Law and Government with the job of rooting out evil that is above } \\
\text { the law. Mike teams up with KITT—an artificially intelligent Ford Shelby } \\
\text { GT500KR - to fight crime in this continuation of the 1980s cult favorite. }\end{array}$ & 3 \\
\hline Kojak & $\begin{array}{l}\text { An independent-minded police detective solves crimes on the streets of New York } \\
\text { City. Lt. Theo Kojak is a bald, lollipop-sucking detective also known for his } \\
\text { trademark catch-phrase, "Who Loves Ya, Baby?" His boss is Capt. Frank MacNeil, } \\
\text { with whom Kojak has a lot in common, who was later promoted to Chief of } \\
\text { Detectives. His most trusted assistants are Det. Bobby Crocker and Det. Stavros. }\end{array}$ & 3 \\
\hline Kojak 2004 & $\begin{array}{l}\text { New York's most famous police lieutenant from the } 70 \text { 's is back! The candy eating, } \\
\text { jazz and fashion loving bald guy hunts criminals again. This time Ving Rhames plays } \\
\text { the role of Theo Kojak. Kojak doesn't do the police work after the book; he fallows } \\
\text { his heart while he searches for the bad guys. His methods are successful, but he needs } \\
\text { protection by his old friend and boss Captain Frank McNeil. }\end{array}$ & 3 \\
\hline $\begin{array}{l}\text { L.A. } \\
\text { Dragnet }\end{array}$ & $\begin{array}{l}\text { This updated version of Dragnet features a group of detectives in the LAPD } \\
\text { Robbery/Homicide Squad investigating crimes that could only take place in Los }\end{array}$ & \\
\hline
\end{tabular}




\begin{tabular}{|c|c|c|}
\hline & $\begin{array}{l}\text { Angeles, one of the world's most glamorous and intriguing cities. Dragnet will draw } \\
\text { storylines from L.A.'s rich crime history, as well as today's headlines. Against the } \\
\text { backdrop of economically and culturally diverse neighborhoods, the detectives come } \\
\text { up against a group of criminals who are just as diverse, from diamond thieves and } \\
\text { Hollywood movie moguls to street gangs, copycat serial killers, international } \\
\text { terrorists and kidnappers. }\end{array}$ & \\
\hline Life & $\begin{array}{l}\text { Damian Lewis stars as a former police officer who, after years of false imprisonment, } \\
\text { returns to the force with a decidedly different philosophy. Deadwood's Robin Weigert } \\
\text { has been added to the cast of the series. She'll play the boss of Lewis' character, Lt. } \\
\text { Davis. Brooke Langton will play the lawyer who got him out of prison that despite } \\
\text { the fact that she is married, has a spark with Lew }\end{array}$ & 3 \\
\hline Lou -Grant & $\begin{array}{l}\text { As the series began, Lou Grant had just been fired from his job at WJM-TV, and had } \\
\text { moved to Los Angeles to work for a newspaper. L.A., a city full of interesting stories, } \\
\text { perfectly made for exciting newspaper reports.... }\end{array}$ & 3 \\
\hline $\begin{array}{l}\text { Mad Mad } \\
\text { House }\end{array}$ & $\begin{array}{l}\text { Mad Mad House is a reality show from the SCIFI Channel, about } 10 \text { ordinary people } \\
\text { who become roommates with a wiccan, a naturist, a vampire, a modern primitive, and } \\
\text { voodoo priestess. }\end{array}$ & 3 \\
\hline Mad Men & $\begin{array}{l}\text { It's New York in the 1960s, and the men and women who work at the Sterling Cooper } \\
\text { Advertising Agency are some of the top names in the industry. Master manipulator } \\
\text { and leading ad man Don Draper is at the top of his game, but there are those who } \\
\text { want to see him topple down. Can he maintain his formidable status? Writer and } \\
\text { executive producer Matthew Weiner of The Sopranos fame is the man... }\end{array}$ & 3 \\
\hline MadTV & $\begin{array}{l}\text { A similar show to Saturday Night Live and In Living Color, sketch comedy series } \\
\text { MADtv mines the world of popular culture for subjects ripe for parody. Based on the } \\
\text { comic stylings of MAD magazine, the series satirizes celebrities, music videos, } \\
\text { television shows, and more through outrageous sketches, a unique assembly of } \\
\text { recurring characters, and the uninhibited zaniness of cast members. }\end{array}$ & 3 \\
\hline $\begin{array}{l}\text { New } \\
\text { Amsterdam }\end{array}$ & $\begin{array}{l}\text { New York City homicide detective John Amsterdam is cursed with immortality } \\
\text { because he stopped the murder of a Native American girl in } 1642 \text { by stepping in front } \\
\text { of a sword. Due to this act of kindness, the girl rescued Amsterdam from the stab } \\
\text { wound by making him immortal, but warns that it is a curse that will only be lifted } \\
\text { when John meets his true love. Now, Amsterdam is a homicide detective in the Big } \\
\text { Apple where he shares his secret with Omar, a blues club owner with a few secrets of } \\
\text { his own. }\end{array}$ & 3 \\
\hline $\begin{array}{l}\text { The } \\
\text { Practice }\end{array}$ & $\begin{array}{l}\text { Set in Boston, The Practice centers on a firm of passionate attorneys to whom every } \\
\text { case is important and every client worth a fight to the end. Legal maneuvering is the } \\
\text { firm's modus operandi, and they have it down to a science, making even the most } \\
\text { questionable arguments convincing. And while they can't — and don't — win every } \\
\text { trial, the pursuit of justice remains the priority until the final verdict is announced ... } \\
\text { and sometimes afterwards. }\end{array}$ & 3 \\
\hline She Spies & $\begin{array}{l}\text { The women of She Spies are three career criminals with one shot at freedom. } \\
\text { Working for the very feds who put them away, the career con-girls have turned their } \\
\text { backs on their former lives, waging weekly war on the lowliest of the world's sleaze } \\
\text { and scumbags, armed with sleek moves, street smarts and enough attitude to make a } \\
\text { sailor blush. }\end{array}$ & 3 \\
\hline T.J. Hooker & $\begin{array}{l}\text { After his partner was murdered, veteran plain clothes Detective T.J. Hooker (William } \\
\text { Shatner) had reverted back to his former role as Sergeant, and returned to the beat to } \\
\text { rid the streets of the type of scum that was responsible for his partner's death. Back in } \\
\text { uniform, Hooker was assigned to train the academy recruits, and was partnered with } \\
\text { brash, sometimes hot-headed young rookie Vince Romano (Adrian Zmed). With } \\
\text { Romano much his junior, Hooker acted as his trainer and mentor on both a } \\
\text { professional and social level. }\end{array}$ & \\
\hline $\begin{array}{l}\text { Tim Gunn's } \\
\text { Guide to }\end{array}$ & $\begin{array}{l}\text { Move over Heidi Klum, everyone's favorite personality on Project Runway gets a } \\
\text { chance to be at the helm of his own show. Using his book Tim Gunn: A Guide to }\end{array}$ & \\
\hline
\end{tabular}




\begin{tabular}{|c|c|c|}
\hline Style & $\begin{array}{l}\text { Quality, Taste \& Style as a point of reference, Gunn will go to work on style- } \\
\text { challenged subjects to inform the masses on his philosophy of dressing, grooming, } \\
\text { and poise. }\end{array}$ & \\
\hline $\begin{array}{l}\text { The } \\
\text { Tonight } \\
\text { Show }\end{array}$ & $\begin{array}{l}\text { Tonight began in June } 1953 \text { as a local show on WNBT-TV, the NBC flagship station } \\
\text { in New York. Steve Allen opens each evening seated at the piano, chatting and } \\
\text { playing some of his own compositions. He then goes to his desk, where he talked } \\
\text { about anything that seemed to interest him. There are guest stars, in addition to his } \\
\text { semi-regulars, but the emphasis is on Steve and his comedic ad-libbing. }\end{array}$ & 3 \\
\hline Valentine & $\begin{array}{l}\text { Greek deities Aphrodite and her son Eros have settled here on Earth and are in the } \\
\text { matchmaking business in this romantic dramedy from The CW. }\end{array}$ & 3 \\
\hline $\begin{array}{l}\text { Caught on } \\
\text { Tape }\end{array}$ & $\begin{array}{l}\text { MSNBC looks at people on the edge -- con artists, tattoo freaks, exorcists and more. } \\
\text { How far will people go if they think no one is watching? What obsessions lurk } \\
\text { beneath the surface? You won't believe it until you see it -- CAUGHT ON TAPE! }\end{array}$ & 3 \\
\hline Cover Me & $\begin{array}{l}\text { Based on the real life adventures of an undercover FBI family. In order to protect his } \\
\text { family, Danny Arno chooses to include his family in his work for the FBI, rather than } \\
\text { hide it from them. }\end{array}$ & 3 \\
\hline Deadline & $\begin{array}{l}\text { New York city journalist Wallace Benton has one aim in life: get the story and get it } \\
\text { right. No matter what the cost. This mentality wreaks havoc on his personal life, but } \\
\text { makes for great reporting. A crumbling marriage, alcoholic tendencies and involving } \\
\text { his journalism students in devious plans to gain info about a story are just a few of the } \\
\text { ways that making a deadline leads Wallace Benton to cross the line. }\end{array}$ & 3 \\
\hline $\begin{array}{l}\text { The } \\
\text { Dresden } \\
\text { Files }\end{array}$ & A Chicago-based wizard works as a private investigator. & 3 \\
\hline $\begin{array}{l}\text { Easy } \\
\text { Money }\end{array}$ & $\begin{array}{l}\text { "Easy Money" is a dramedy set in the world of a Southwestern loan shark family. Led } \\
\text { by business-savvy matriarch Bobette Buffkin (Laurie Metcalf "Roseanne"), Prestige } \\
\text { Payday Loans is a thriving quick-cash company. But trouble quickly comes from } \\
\text { thuggish new competitors, the Mamayo Brothers, and it's up to middle son Morgan } \\
\text { (Jeff Hephner "The O.C.") to quash any tension. }\end{array}$ & 3 \\
\hline ECW & Extreme Championship Wrestling with Joey Styles and Tazz. & 3 \\
\hline Eureka & $\begin{array}{l}\text { Eureka takes place in a high tech community of the same name, located somewhere in } \\
\text { the Pacific Northwest (implied in various episodes to be Oregon) and inhabited } \\
\text { entirely by brilliant scientists working on new scientific advancements for the United } \\
\text { States government that frequently go disastrously awry. The town's existence and } \\
\text { location is a closely guarded secret. U.S. Marshal Jack Carter stumbles upon Eureka } \\
\text { while transporting a fugitive prisoner - his own rebellious teenage daughter Zoe- } \\
\text { back to her mother's home in Los Angeles, California. When a faulty experiment } \\
\text { cripples the sheriff of Eureka, Carter finds himself quickly chosen to fill the vacancy. } \\
\text { Despite not being at the genius level of most of the town, Jack Carter's ability to } \\
\text { connect what others do not see repeatedly saves Eureka, and indeed the entire world, } \\
\text { from one would-be disaster after another. }\end{array}$ & 3 \\
\hline $\begin{array}{l}\text { Hell's } \\
\text { Kitchen }\end{array}$ & $\begin{array}{l}\text { A former-pro-soccer-player-turned-Michelin-starred-chef, Gordon Ramsay is looking } \\
\text { for someone with the potential to become America's next culinary star. The heat is on } \\
\text { and the "steaks" are high as the contestants endure Ramsay's hellishly intense } \\
\text { culinary boot camp. Each week Ramsay will grill the ambitious hopefuls as they } \\
\text { attempt to prove they have what it takes to run their own restaurant. }\end{array}$ & \\
\hline Heroes & $\begin{array}{l}\text { An epic drama that chronicles the lives of ordinary people: a genetics professor, a } \\
\text { hospice nurse, a single mom, a street cop, a small town cheerleader, a tormented } \\
\text { artist, a computer geek-coming to grips with newly found remarkable powers. }\end{array}$ & \\
\hline $\begin{array}{l}\text { Hill Street } \\
\text { Blues }\end{array}$ & $\begin{array}{l}\text { Before "NYPD Blue" and "The Shield" came "Hill Street Blues," the series that } \\
\text { revolutionized the TV cop show by giving television viewers a realistic glimpse into } \\
\text { the daily lives of the officers and detectives at an urban police station. Earning } 98 \\
\text { Emmy nominations over its seven-year run, "Hill Street Blues" was one of the most } \\
\text { innovative and critically acclaimed shows of the 1980s. }\end{array}$ & \\
\hline
\end{tabular}




\begin{tabular}{|c|c|c|}
\hline $\begin{array}{l}\text { The } \\
\text { Incredible } \\
\text { Hulk }\end{array}$ & $\begin{array}{l}\text { A research scientist, who changes into a green man monster when angered, searches } \\
\text { for an antidote. }\end{array}$ & 3 \\
\hline $\begin{array}{l}\text { The } \\
\text { Invisible } \\
\text { Man }\end{array}$ & $\begin{array}{l}\text { As a scientist working for a government think-tank called the KLAE Corporation, Dr. } \\
\text { Daniel Westin creates a formula to be used for matter transformation. To test the } \\
\text { formula he uses it on himself. Before he can return to normal he discovers the } \\
\text { government wants to use his formula for wrong, so he destroys it. }\end{array}$ & 3 \\
\hline $\begin{array}{l}\text { Lost in } \\
\text { Space }\end{array}$ & $\begin{array}{l}\text { In 1997, Earth has squandered its natural resources. The Robinson family departs } \\
\text { Earth on the Jupiter } 2 \text { in search of a habitable planet for mankind to colonize. } \\
\text { However, a spy from a foreign country, Dr. Smith, becomes trapped aboard while } \\
\text { trying to sabotage the ship. Dr. Smith's extra weight causes the Jupiter } 2 \text { to be thrown } \\
\text { off course. }\end{array}$ & 4 \\
\hline Maury & $\begin{array}{l}\text { The host, Maury, helps people with their problems and other issues they need to work } \\
\text { on. He helps families sort out their differences and help friends come closer together. } \\
\text { He also helps young parents or soon to be young parents tell their own parents about } \\
\text { their situation. He also helps people confront their crushes and brings them together. }\end{array}$ & 4 \\
\hline $\begin{array}{l}\text { Murder } \\
\text { One }\end{array}$ & $\begin{array}{l}\text { Theodore Hoffman is a prominent defense attorney in a prestigious Los Angeles law } \\
\text { firm. After successfully defending the wealthy but suspicious Richard Cross in a lurid } \\
\text { murder trial, he is now involved in the defense of Neil Avedon. Neil is a famous } \\
\text { young actor who has had severe drug and alcohol problems and was subsequently } \\
\text { charged with the murder, after Cross was exonerated. }\end{array}$ & 4 \\
\hline $\begin{array}{l}\text { The } \\
\text { Rockford } \\
\text { Files }\end{array}$ & $\begin{array}{l}\text { James Garner stars as Jim Rockford, a private investigator who lives and works from } \\
\text { his trailer in Malibu, Los Angeles. Jim is an ex-con who had been imprisoned for five } \\
\text { years in San Quentin for armed robbery - a crime which he did not commit and was } \\
\text { later pardoned. }\end{array}$ & 4 \\
\hline S.W.A.T. & $\begin{array}{l}\text { S.W.A.T. is a program inspired by the real-life crime-control units that rose to } \\
\text { prominence in the U.S. after the civil disturbances of the late 1960's. It was a spin-off } \\
\text { of the popular ABC cop drama The Rookies. This particular 'Special Weapons And } \\
\text { Tactics' unit was an elite five-man team of police officers who dealt with situations } \\
\text { that were too dangerous for the police force to handle. }\end{array}$ & 4 \\
\hline Sanctuary & $\begin{array}{l}\text { Dr. Helen Magnus is one of the first female doctors in the Royal College during } \\
\text { Victorian England. Dr. Magnus takes over her fathers' sanctuary for supernatural } \\
\text { creatures, collected from all over the world. In her work with these creatures, Dr. } \\
\text { Magnus has received age longevity. She is joined by her daughter Ashley, played by } \\
\text { Emilie Ullerup, and young psychiatric resident Dr. Will Zimmerman, played by } \\
\text { Robin Dunne, who may have what it takes to become her new protégé. }\end{array}$ & 4 \\
\hline Sliders & $\begin{array}{l}\text { "What if you could find brand new worlds right here on Earth, where anything is } \\
\text { possible: same planet, different dimension? I found the gateway!" In his basement in } \\
\text { San Francisco, boy-genius Quinn Mallory unlocks the doorway to an infinite number } \\
\text { of Earths. He "slides" from world to world, not only adapting to his changing } \\
\text { surroundings, but also trying to get home. }\end{array}$ & 4 \\
\hline Standoff & $\begin{array}{l}\text { Matt Flannery and Emily Lehman are top-ranked crisis negotiators in the FBI's Crisis } \\
\text { Negotiation Unit who are trained to talk their way through volatile situations. They } \\
\text { make an outstanding team professionally, but their relationship is a bit more } \\
\text { precarious off the job. The series advances the fundamental idea that in life and in } \\
\text { love "Everything is a negotiation." }\end{array}$ & 4 \\
\hline $\begin{array}{l}\text { Team } \\
\text { Knight } \\
\text { Rider }\end{array}$ & $\begin{array}{l}\text { Ten years ago...all it took was one man, and one car, to get the job done. Now...the } \\
\text { Foundation for Law and Goverment, has assembled five highly skilled operatives, } \\
\text { and paired them with the most advanced state of the art vehicles, to take on a new } \\
\text { breed of outlaw. They are...Team Knight Rider. }\end{array}$ & \\
\hline $\begin{array}{l}\text { Tequila \& } \\
\text { Bonetti }\end{array}$ & $\begin{array}{l}\text { Modeled after the movie Turner and Hooch, the series followed the adventures of a } \\
\text { New York cop in a California beach town. His partner was a dog whose thoughts } \\
\text { were voiced for the audience to hear. }\end{array}$ & \\
\hline Total & Detective David Hume and his android partner Ian Farve investigate crimes in the & 4 \\
\hline
\end{tabular}




\begin{tabular}{|c|c|c|}
\hline $\begin{array}{l}\text { Recall } \\
2070\end{array}$ & $\begin{array}{l}\text { year 2070. The series is based on works by author Philip K. Dick that were adapted } \\
\text { into the film Total Recall starring Arnold Schwarzenegger and Sharon Stone. }\end{array}$ & \\
\hline $\begin{array}{l}\text { Are You } \\
\text { Smarter } \\
\text { Than a } 5^{\text {th }} \\
\text { Grader }\end{array}$ & $\begin{array}{l}\text { Jeff Foxworthy hosts this game show in which contestants try to answer questions } \\
\text { from elementary school in order to win one million dollars. Across a variety of } \\
\text { subjects, contestants choose } 1 \text { st grade through } 5 \text { th grade level questions as they } \\
\text { progress from } \$ 1,000 \text { to } \$ 1,000,000 \text {. Helping them out with the answers is a group of } \\
\text { actual fifth graders who team up with the contestants when necessary. }\end{array}$ & 4 \\
\hline $\begin{array}{l}\text { AST Dew } \\
\text { Tour }\end{array}$ & $\begin{array}{l}\text { ST Dew Tour is a ballerina sports tour that consists of five major, multi-sport events } \\
\text { spanning across the country, with a cumulative points system, a } \$ 2.5 \text { million } \\
\text { competitive purse - the largest in action sports. }\end{array}$ & 4 \\
\hline $\begin{array}{l}\text { Burn } \\
\text { Notice }\end{array}$ & $\begin{array}{l}\text { After fleeing a Nigerian operation blown apart by the sudden and unexplained non- } \\
\text { cooperation of his U.S. contact, Westen finds himself in his hometown[3] of Miami, } \\
\text { Florida, USA, attended to by his ex-girlfriend but abandoned by all his normal } \\
\text { intelligence contacts, under continuous surveillance with his personal assets frozen. } \\
\text { Extraordinary efforts to reach his U.S. government handler eventually yield only a } \\
\text { grudging admission that someone powerful wants him "on ice" in Miami; if he leaves } \\
\text { the city he will "heat up fast", i.e., he will be hunted down and taken into custody, } \\
\text { whereas by staying there he can remain relatively free. Consumed by the desire to } \\
\text { find out why he's been burned, and by whom, Westen goes to work as an unlicensed } \\
\text { private investigator and freelance spy for anyone in town who can pay him any } \\
\text { money in order to fund his personal investigation into his own situation as a } \\
\text { blacklisted agent. }\end{array}$ & 4 \\
\hline $\begin{array}{l}\text { The Crow: } \\
\text { Stairway to } \\
\text { Heaven }\end{array}$ & $\begin{array}{l}\text { Eric Draven, a musician, and his fiancée, a photographer, are murdered. One year } \\
\text { after their death, Eric returns from the dead, but has been changed. Eric remembers } \\
\text { little by little what happened to him and finds those which destroyed his life. He then } \\
\text { kills them off one by one until he finds the head of the organization the murderers } \\
\text { work for. }\end{array}$ & 4 \\
\hline $\begin{array}{l}\text { Decision } \\
\text { House }\end{array}$ & $\begin{array}{l}\text { "Decision House" is an intense real-life look at couples struggling to hold on to their } \\
\text { relationships, as they try one last time to find happily ever after. In "Decision House" } \\
\text { Judge Lynn Toler ("Divorce Court") and a panel of experts, including well-known } \\
\text { family and marriage therapist Dr. Tara Fields ("Intervention"), help couples on the } \\
\text { brink of disaster tackle issues ranging from financial hardships to infidelity. }\end{array}$ & 4 \\
\hline $\begin{array}{l}\text { Equal } \\
\text { Justice }\end{array}$ & $\begin{array}{l}\text { A contemporary drama focusing on the personal and professional lives of the men } \\
\text { and women in a big city's District Attorney's office. Moving, dramatic, irreverent and } \\
\text { funny, the drama offers an incisive look at the workings of the American criminal } \\
\text { justice system as seen through the eyes of those who are its daily defenders in court, } \\
\text { as well as from the perspective of those accused of committing crimes. }\end{array}$ & 4 \\
\hline $\begin{array}{l}\text { Galactica } \\
1980\end{array}$ & $\begin{array}{l}\text { The fight continues against the Cylons, in this, the sequel to the original Battlestar } \\
\text { Galactica. }\end{array}$ & 4 \\
\hline $\begin{array}{l}\text { Ghost } \\
\text { Hunters }\end{array}$ & Ghost hunters investigate haunted houses throughout the country. & 4 \\
\hline $\begin{array}{l}\text { Ghost } \\
\text { Hunters } \\
\text { Internation } \\
\text { al }\end{array}$ & Paranormal investigators examine haunted locations around the world. & 4 \\
\hline $\begin{array}{l}\text { Hart to } \\
\text { Hart }\end{array}$ & $\begin{array}{l}\text { Robert Wagner and Stephanie Powers are Jonathan and Jennifer Hart, a pair of } \\
\text { wealthy amateur sleuths. He and his wife Jennifer are able to live the high life, but, } \\
\text { their inquisitiveness keep them constantly caught between glamour and danger. }\end{array}$ & \\
\hline I Spy & $\begin{array}{l}\text { I Spy is an American television secret agent action adventure series about a pair of } \\
\text { American agents facing espionage adventures with skill, humor and ingenuity, which } \\
\text { aired on NBC from } 1965 \text { to } 1968 \text {. }\end{array}$ & 4 \\
\hline $\begin{array}{l}\text { It Takes a } \\
\text { Thief }\end{array}$ & $\begin{array}{l}\text { Alexander Mundy was a cat burglar and professional thief who had style, class and } \\
\text { talent. He made only one mistake -- getting caught. While serving a sentence in San } \\
\text { Jobel Prison, he was contacted by representatives of the US Government spy agency, }\end{array}$ & 4 \\
\hline
\end{tabular}




\begin{tabular}{|c|c|c|}
\hline & $\begin{array}{l}\text { SIA. They offered to get him out if he would put his talents to work stealing for the } \\
\text { government. Accepting the offer, he worked closely with an SIA. }\end{array}$ & \\
\hline $\begin{array}{l}\text { Alfred } \\
\text { Hitchcock } \\
\text { Hour }\end{array}$ & $\begin{array}{l}\text { The Alfred Hitchcock Hour was a mystery and suspense anthology hosted by the } \\
\text { master of supsense Alfred Hitchcock. Each } 60 \text { minute episode included opening and } \\
\text { closing vingettes featuring Hitchcock who would often explain some aspect of the } \\
\text { day's show and would often offer subtle (or not so subtle) jabs at the shows sponsors. }\end{array}$ & 5 \\
\hline $\begin{array}{l}\text { Alias Smith } \\
\text { and Jones }\end{array}$ & $\begin{array}{l}\text { Hannibal Heyes and Kid Curry, two successful and popular outlaw cousins in the old } \\
\text { West, decide it's time to go straight. The problem is that the governor just can't give } \\
\text { them amnesty right away, they have to prove that they deserve it. And in the } \\
\text { meantime they will still be wanted. Hunting them is everybody, from sheriffs to } \\
\text { bounty hunters, to posses and ordinary people. }\end{array}$ & 5 \\
\hline $\begin{array}{l}\text { Land of the } \\
\text { Giants }\end{array}$ & $\begin{array}{l}\text { This two-season series details the adventures of the three crew and four passengers of } \\
\text { the sub-orbital spacecraft Spindrift. They are drawn through a space warp that crashes } \\
\text { them onto a planet where everything is } 12 \text { times normal size. The castaways struggle } \\
\text { to repair their damaged craft and somehow get back to Earth while being hunted by } \\
\text { the totalitarian government that rule the planet }\end{array}$ & 5 \\
\hline $\begin{array}{l}\text { Night } \\
\text { Gallery }\end{array}$ & $\begin{array}{l}\text { Night Gallery was creator-host Rod Serling's follow-up to The Twilight Zone. Set in } \\
\text { a shadowy museum of the outre, Serling weekly unveiled disturbing portraiture as } \\
\text { preface to a highly diverse anthology of tales in the fantasy-horror vein. Bolstering } \\
\text { Serling's thoughtful original dramas were adaptations of classic genre material--short } \\
\text { stories by such luminaries as H. P. Lovecraft, Fritz Leiber, A.E. van Vogt, Algernon } \\
\text { Blackwood, Conrad Aiken, Richard Matheson, August Derleth, and Christianna } \\
\text { Brand. Variety of material brought with it a variety of tone, from the deadly serious to } \\
\text { the tongue-in-cheek, stretching the television anthology concept to its very limit }\end{array}$ & 5 \\
\hline $\begin{array}{l}\text { Peacemake } \\
\text { rs }\end{array}$ & $\begin{array}{l}\text { The Western Frontier is disappearing as encroaching civilization and the industrial } \\
\text { age meet in } 1882 \text {. Nowhere is the clash of the old and new more evident than in law } \\
\text { enforcement. With the advent of such innovations as fingerprinting and photography, } \\
\text { modern police investigation is born. Peacemakers revolves around the often } \\
\text { contentious relationship between a grizzled, middle-aged Federal Marshall played by } \\
\text { Tom Berenger ("Platoon," "Major League") and his cocky young deputy played by } \\
\text { Peter O'Meara ("Band of Brothers"), who is a former Pinkerton agent from Chicago } \\
\text { with a degree from Yale and a wagonload of forensic equipment. }\end{array}$ & 5 \\
\hline $\begin{array}{l}\text { Picket } \\
\text { Fences }\end{array}$ & $\begin{array}{l}\text { Sherrif James Brock (Tom Skerrit) is trying to maintain the small town of Rome, } \\
\text { Wisconin. Trying his best to keep the town in order, Judge Henry Bone (Ray } \\
\text { Walston) rules the court room and while he doesn't always stick to the law, he does } \\
\text { what is best for the town. Making Judge Bone's job harder is lawer Douglas } \\
\text { Wambaugh (Fyvush Finkel), a friend of Judge Bone but an enemy in the court room. }\end{array}$ & 5 \\
\hline Red Eye & $\begin{array}{l}\text { The show is officially titled "Red Eye with Greg Gutfeld" and is set up as a } \\
\text { discussion group akin to "The McLaughlin Group." The similarity ends there. On this } \\
\text { late night show, the outrageous and outspoken gather with Greg Gutfeld to discuss } \\
\text { the news and the hottest topics of the day. Among the regular panelists are recurring } \\
\text { guests Bill Shultz, Kevin Godlington, Will Durst, and Rachel Marsden. Greg } \\
\text { Gutfeld's mother } 82 \text { year-old serves as "Senior Correspondent" and phones in her } \\
\text { reviews from California with the senior citizen perspective. }\end{array}$ & 5 \\
\hline $\begin{array}{l}\text { The Search } \\
\text { for the } \\
\text { Next Elvira }\end{array}$ & $\begin{array}{l}\text { The next Elvira lives among us, and the original Mistress of the Dark searches for the } \\
\text { new Elvira with a series of tasks and challenges to see which of the thirteen hopefuls } \\
\text { is worthy of becoming the new apprentice to the Mistress. }\end{array}$ & 5 \\
\hline Tremors & $\begin{array}{l}\text { This spinoff of the Tremor movies chronicles the town of Perfection, Nevada, which } \\
\text { has a little problem with great big worms. The Graboids, and their offspring the } \\
\text { Shriekers and Ass-Blasters, have overrun the valley but are on the government's } \\
\text { protected species list. The locals are (barely) allowed to live there rather then leave } \\
\text { their homes, as long as they don't harm the creatures, particularly the giant Graboid } \\
\text { known as "El Blanco"... }\end{array}$ & \\
\hline America's & "America's Toughest Jobs" is a new extreme competition series that will test 13 men & \\
\hline
\end{tabular}




\begin{tabular}{|c|c|c|}
\hline $\begin{array}{l}\text { Toughest } \\
\text { Jobs }\end{array}$ & $\begin{array}{l}\text { and women who venture out of their safe and comfortable careers and are injected } \\
\text { into some of the most challenging, dangerous and demanding jobs on earth. From } \\
\text { logging high in the Oregon forest to oil drilling on the Texas range, and driving icy } \\
\text { roads to extreme fishing - each job requires guts and stamina, and the competitors } \\
\text { will have to live up to the same standards as the pros. At the end of each episode, } \\
\text { their new boss and co-workers will determine success or failure, and those who don't } \\
\text { make the grade will be sent home. Upping the ante, the annual salary of each job will } \\
\text { be thrown into the pot until the finale - where one rookie will take home the well- } \\
\text { earned cash. }\end{array}$ & \\
\hline $\begin{array}{l}\text { American } \\
\text { Gothic }\end{array}$ & $\begin{array}{l}\text { The story takes place in the fictional town of Trinity, South Carolina, and revolves } \\
\text { around Caleb Temple (Lucas Black) and the town's corrupt Sheriff, Lucas Buck } \\
\text { (Gary Cole). Though appearing affable and charismatic, Sheriff Lucas Buck is a } \\
\text { murderous rapist whose powerbase is backed by apparent supernatural powers, which } \\
\text { he generally uses to manipulate people to "fulfill their potential" and make life- } \\
\text { changing choices (usually for evil). Caleb Temple is a normal child whose paternity } \\
\text { masks a horrific secret: Lucas Buck is his biological father, having raped his mother } \\
\text { in front of Caleb's older sister Merlyn (Sarah Paulson). The horror of watching her } \\
\text { mother be sexually assaulted caused Merlyn to become severely emotionally } \\
\text { traumatized and withdrawn from the rest of the world, made even worse when her } \\
\text { mother committed suicide after giving birth to Caleb. }\end{array}$ & 5 \\
\hline $\begin{array}{l}\text { Another } \\
\text { World }\end{array}$ & $\begin{array}{l}\text { Set in the fictional Bay City, Another World focused less on the conventional drama } \\
\text { of domestic life as seen in other soap operas, and more on exotic melodrama seen } \\
\text { between families of different classes and philosophies, the philosophy emphasized by } \\
\text { the line read at the beginning of each show, 'We do not live in this world alone, but in } \\
\text { a thousand other worlds." A multiple Daytime Emmy Award winning serial, Another } \\
\text { World has the distinction of being the first daytime soap to expand to an hour, of } \\
\text { showcasing the most elegant sets and costuming daytime has ever known, and heavily } \\
\text { recruiting actors and directors from the New York stage to make Another World } \\
\text { considered to have had one of the most talented casts in daytime television. }\end{array}$ & 5 \\
\hline Babylon 5 & $\begin{array}{l}\text { Politics, diplomacy and conflict converge at the Babylon } 5 \text { space station from which } \\
\text { the popular science fiction television series centers. }\end{array}$ & 5 \\
\hline $\begin{array}{l}\text { Battle } \\
\text { Dome }\end{array}$ & $\begin{array}{l}\text { Julie Brown hosts an exciting new action sports competition pitting two teams of } \\
\text { amateur athletes against a team of ten super athletes - the biggest and fiercest men } \\
\text { and women who will stop at nothing to destroy every challenger who comes before } \\
\text { them. }\end{array}$ & 5 \\
\hline $\begin{array}{l}\text { Battlestar } \\
\text { Galactica }\end{array}$ & $\begin{array}{l}\text { Battlestar Galactica continues from the } 2003 \text { mini-series to chronicle the journey of } \\
\text { the last surviving humans from the Twelve Colonies of Man after their nuclear } \\
\text { annihilation by the Cylons. The survivors are led by President Laura Roslin and } \\
\text { Commander (later Admiral) William Adama in a ragtag fleet of ships with the } \\
\text { Battlestar Galactica, a powerful but out-dated warship at its head. Pursued by Cylons } \\
\text { intent on wiping out the remnants of the human race, the survivors travel across the } \\
\text { galaxy looking for the fabled and long-lost thirteenth colony: Earth. }\end{array}$ & 5 \\
\hline $\begin{array}{l}\text { Battlestar } \\
\text { Galactica } \\
\text { Classic }\end{array}$ & $\begin{array}{l}\text { From an ancient civilization of humans, a fleet of starships --led by battlestar } \\
\text { Galactica--search a lost and last remaining colony called, Earth, after the Cylons, } \\
\text { their mortal enemies, destroy all other habitable colonies. }\end{array}$ & 5 \\
\hline $\begin{array}{l}\text { Buck } \\
\text { Rogers }\end{array}$ & $\begin{array}{l}\text { A 20th century astronaut emerges out of } 500 \text { years of suspended animation into a } \\
\text { future time where Earth is threatened by alien invaders. }\end{array}$ & \\
\hline Emergency & $\begin{array}{l}\text { The series followed the early years of the Paramedic program in the Los Angeles } \\
\text { County Fire Department (LACoFD) with the focus on the personnel of Fire Station } \\
\text { 51, in particular Firefighter/Paramedics John Gage (Randolph Mantooth) and Roy } \\
\text { DeSoto (Kevin Tighe). }\end{array}$ & 5 \\
\hline $\begin{array}{l}\text { Fantasy } \\
\text { Island }\end{array}$ & $\begin{array}{l}\text { Imagine a place where any dream, any fantasy, can come true. Such a place exists: } \\
\text { welcome to "Fantasy Island." Your host is Mr. Rourke, a charming gentleman who, } \\
\text { along with his diminutive assistant, Tattoo, will see to it that your island visit is all }\end{array}$ & \\
\hline
\end{tabular}




\begin{tabular}{|c|c|c|}
\hline & & \\
\hline Flipper & $\begin{array}{l}\text { The weekly series takes place in and around the Bal Harbor Institute, a marine } \\
\text { mammal research facility set in the beautiful Florida Keys, where ground-breaking } \\
\text { studies are being conducted on dolphin behavior. The institute and the new Monroe } \\
\text { County Search \& Rescue Sheriff's Substation, set the stage for highly dramatic air } \\
\text { and sea rescues involving Flipper, one of the most loved and enduring TV characters } \\
\text { of all time, and his human companions. }\end{array}$ & 5 \\
\hline $\begin{array}{l}\text { In Harm's } \\
\text { Way }\end{array}$ & $\begin{array}{l}\text { Hosted by Hunter Ellis (Hunter Ellis), former Navy Fighter Pilot and one of People } \\
\text { Magazine's } 50 \text { most beautiful people in the world, each episode documents the stories } \\
\text { of the brave individuals who risk their lives in a multitude of life-threatening jobs, all } \\
\text { for the benefit of society. }\end{array}$ & 5 \\
\hline Ironside & $\begin{array}{l}\text { When an assassin's bullet confines him to a wheelchair for life ending his career as } \\
\text { Chief of Detectives, Robert T. Ironside becomes a consultant to the police } \\
\text { department. Detective Sergeant Ed Brown and policewoman Eve Whitfield join with } \\
\text { him to crack varied and fascinating cases. }\end{array}$ & 5 \\
\hline Lock-Up & $\begin{array}{l}\text { Every week in the late } 1950 \text { 's Lock Up revealed for American television viewers an } \\
\text { account of the unjustly accused. The shows broader theme is that when individuals } \\
\text { are charged with a crime not all is as it first appears and a thorough investigation is } \\
\text { duly warranted in order to ferret out the vital facts pertinent to the case. }\end{array}$ & 6 \\
\hline $\begin{array}{l}\text { Meet the } \\
\text { Presidents }\end{array}$ & $\begin{array}{l}\text { Meet the Presidents is the longest-running network television show in history. Since } \\
\text { 1947, the program has been asking the hard questions in unrehearsed, news-making } \\
\text { interviews with the movers and shakers of the world: top government officials, } \\
\text { political leaders, heads of state, and presidents. These are the people who helped } \\
\text { shape history, and here are their appearances on Meet the Press -- uncut, as they } \\
\text { originally aired! }\end{array}$ & 6 \\
\hline $\begin{array}{l}\text { National } \\
\text { Geographic } \\
\text { Channel }\end{array}$ & $\begin{array}{l}\text { A series of documentaries that covers a diverse number of subjects including the } \\
\text { natural world of wild creatures, native cultures, historical discoveries, etc. They range } \\
\text { from a Nazi Expedition to Monkey Hunters, all the way to the Penguin Death Zone, } \\
\text { and exploring the Year of the Hamster. }\end{array}$ & 6 \\
\hline $\begin{array}{l}\text { NBC News } \\
\text { on Stage }\end{array}$ & $\begin{array}{l}\text { Stars on Stage- NBC news presents them all: Madonna, U2, Letterman, The Rolling } \\
\text { Stones....NBC looks behind the scenes and presents astonishing facts about stars in } \\
\text { stage. }\end{array}$ & 6 \\
\hline $\begin{array}{l}\text { NBC News } \\
\text { Special }\end{array}$ & $\begin{array}{l}\text { NBC News brings its worldwide resources to these in-depth special programs. Brian } \\
\text { Williams takes the lead in covering topics that enlighten, uplift or demand further } \\
\text { scrutiny. Important stories of our time; these are the stories of NBC News Specials. }\end{array}$ & 6 \\
\hline $\begin{array}{l}\text { NBC News } \\
\text { Time } \\
\text { Capsule }\end{array}$ & $\begin{array}{l}\text { NBC News has been covering the events of the nation and the world for decades, } \\
\text { amassing one of the finest and most extensive archives anywhere. Here's where you } \\
\text { can find some of the real treasures in our collection, many of them now available for } \\
\text { the first time. Vintage programs, interviews and news coverage, offering a unique and } \\
\text { fascinating perspective on our times. }\end{array}$ & 6 \\
\hline NOVA & $\begin{array}{l}\text { Seen in more than } 100 \text { countries, NOVA is the most watched science television series } \\
\text { in the world and the most watched documentary series on PBS. Each week NOVA } \\
\text { takes an in depth look at a particular topic or individual in the science field. NOVA's } \\
\text { topics cover all branches of science and engineering. NOVA's unique way of } \\
\text { presenting each topic can be interesting to both those with no prior knowledge or } \\
\text { those whose life's work is being covered. }\end{array}$ & 6 \\
\hline $\begin{array}{l}\text { Outer } \\
\text { Limits }\end{array}$ & $\begin{array}{l}\text { Like the classic 1960s series of the same name, each episode is a celebration of the } \\
\text { human imagination in which humanity's exploration of new frontiers in technology, } \\
\text { outer space and the human experience reveal our greatest hopes and darkest fears. } \\
\text { Stories on The Outer Limits have explored the consequences of such controversial } \\
\text { and thought-provoking topics as genetic manipulation, alien visitation and life after } \\
\text { death }\end{array}$ & 6 \\
\hline Surface & $\begin{array}{l}\text { Ever wonder what life would be like if a new form of sea life began to appear in } \\
\text { locales all over the earth? "Surface" is an expansive drama and undersea adventure }\end{array}$ & 6 \\
\hline
\end{tabular}




\begin{tabular}{|c|c|c|}
\hline & & \\
\hline $\begin{array}{l}\text { Tom } \\
\text { Brokaw } \\
\text { Reports }\end{array}$ & $\begin{array}{l}\text { His insightful coverage of world events, from Watergate to the fall of the Berlin Wall } \\
\text { to the war in Iraq, made Tom Brokaw one of the most respected names in journalism. } \\
21 \text { years as anchor of NBC Nightly News honed his reporting style and earned } \\
\text { America's trust. Where Tom Brokaw leads, an interesting story is sure to follow. }\end{array}$ & 6 \\
\hline $\begin{array}{l}\text { Voyage to } \\
\text { the Bottle } \\
\text { of the Sea }\end{array}$ & $\begin{array}{l}\text { Voyage to the Bottom of the Sea, an action-filled and entertaining adventure series, is } \\
\text { the brainchild of Writer/Producer/Director Irwin Allen... the "Master of Disaster." } \\
\text { The submarine Seaview, the world's only privately owned nuclear sub, investigates } \\
\text { the mysteries and dangers of the sea. }\end{array}$ & 6 \\
\hline $\begin{array}{l}\text { Wired } \\
\text { Science }\end{array}$ & $\begin{array}{l}\text { "Wired Science" brings the cutting-edge technology stories from Wired Magazine to } \\
\text { life. This one-hour primetime program features stories on recent discoveries, the } \\
\text { latest innovations, and breakout ideas. }\end{array}$ & 6 \\
\hline $\begin{array}{l}\text { Barrett- } \\
\text { Jackson: } \\
\text { Life Off } \\
\text { the Block }\end{array}$ & $\begin{array}{l}\text { A series of four one-hour specials in which cameras follow Craig Jackson, Steve } \\
\text { Davis and various consigners and bidders behind-the scenes, before, during, and after } \\
\text { the } 2005 \text { Scottsdale Auction. }\end{array}$ & 6 \\
\hline Carrier & $\begin{array}{l}\text { In the middle of the ocean, a thousand miles from nowhere, a floating city rises above } \\
\text { the sea. Twenty-four stories high, three football fields long, carrying 5,000 sailors and } \\
\text { marines and } 85 \text { military aircraft - this is the USS Nimitz. From May to November } \\
\text { 2005, a team of documentary filmmakers embedded aboard the USS Nimitz as it } \\
\text { deployed to the Persian Gulf in support of Operation Iraqi Freedom. The result is a } \\
\text { raw and honest look at the United States Navy and its role at a critical turning point in } \\
\text { the controversial war. With startling intimacy, CARRIER follows a core group of } \\
\text { subjects as they navigate personal conflicts around their jobs, family, faith, } \\
\text { patriotism, and the rites of passage - all against the extraordinary backdrop of the war } \\
\text { in Iraq. }\end{array}$ & 6 \\
\hline $\begin{array}{l}\text { Destination } \\
\text { Truth }\end{array}$ & $\begin{array}{l}\text { The series follows paranormal researcher Joshua Gates around the world to } \\
\text { investigate claims of the supernatural, mainly in the field of cryptozoology. }\end{array}$ & 6 \\
\hline $\begin{array}{l}\text { Fox News } \\
\text { Specials }\end{array}$ & Specials and Documentaries about our world today. & 6 \\
\hline
\end{tabular}




\section{Appendix E}

\section{Day 1}

\section{SCREEN 1 - Both Conditions}

Tomorrow when you return to this lab you will all be watching films and eating snacks. Note as you consider any film viewing selections that you will be monitored during the hour film viewing period to ensure that you are paying attention, and anyone caught sleeping, reading e-mail, doing work, or not paying attention for any other reason will NOT receive their $\$ 30$ study completion payment - they will only receive their $\$ 10$ show-up fee. Also, note that you will be required to throw away any uneaten snacks you are given during tomorrow's session - snacks may not be taken out of the lab.

\section{Click Here}

\section{SCREEN 2 - Both Conditions}

\section{Research Study}

Please enter your USER ID here (this number was given to you by the experimenter):

Submit Screen 1

\section{SCREEN 3 - Both Conditions}

\section{Research Study}

There is research suggesting that people experience internal conflict when choosing between things they feel they should do but don't particularly want to do ("should" options) and things they want to do but don't feel they should do ("want" options). Should options are typically less instantly gratifying but provide more long-term value than want options. To give a concrete example, a greasy slice of pizza (which tastes great but is quite unhealthy) is more of a want option and less of a should option than a simple salad (which often tastes just so-so but is quite healthy)

Consider the following choice that a person could face:

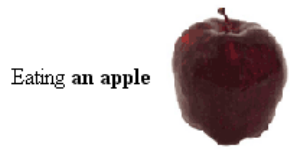

or

Eating a package of M\&Ms
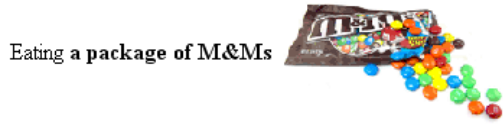

\footnotetext{
1. Which option do you think is more of a should choice?

$O$ Eating an apple.

Eating a package of $\mathrm{M} \& \mathrm{Ms}$

2. Which option do you think is more of a want choice?

Eating an apple.

$O$ Eating a package of M\&Ms 


\section{SCREEN 4 - Uncertainty Condition}

\section{Research Study}

\section{Tomorrow a coin flip will determine}

Which of the following television shows you watch for 1 hour:

(1) The A Team (see description below).

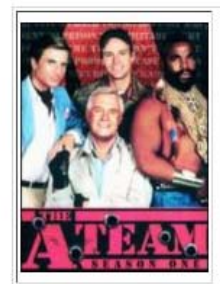

"In 1972 a crack commando unit was sent to prison by a military court for a crime they didn't commit. These men promptly escaped from a maximum security stockade to the Los Angeles underground. Today, still wanted by the government, they survive as soldiers of fortune. If you have a problem, if no one else can help, and if you can find them, maybe you can hire: THE A-TEAM."

(2) Alfred Hitchcock Hour (see description below).

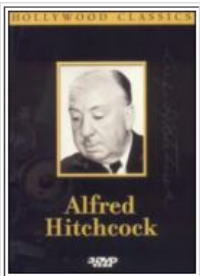

The Alfred Hitchcock Hour was a mystery and suspense anthology hosted by the master of supsense Alfred Hitchcock. Each 60 minute episode included opening and closing vingettes featuring Hitchcock who would often explain some aspect of the day's show and would often offer subtle (or not so subtle) jabs at the shows sponsors.

NOTE: We will monitor you tomorrow while you are watching the show to ensure that you are paying attention. If we find that you are not paying attention (because you fall asleep, are reading a book, etc.), you will only receive a show-up fee of $\$ 10$ and no additional $\$ 30$. 


\section{SCREEN 4 - Certainty Condition}

\section{Research Study}

\section{Tomorrow it has been determined that you will watch}

The following television show for 1 hour:

The A Team (see description below).

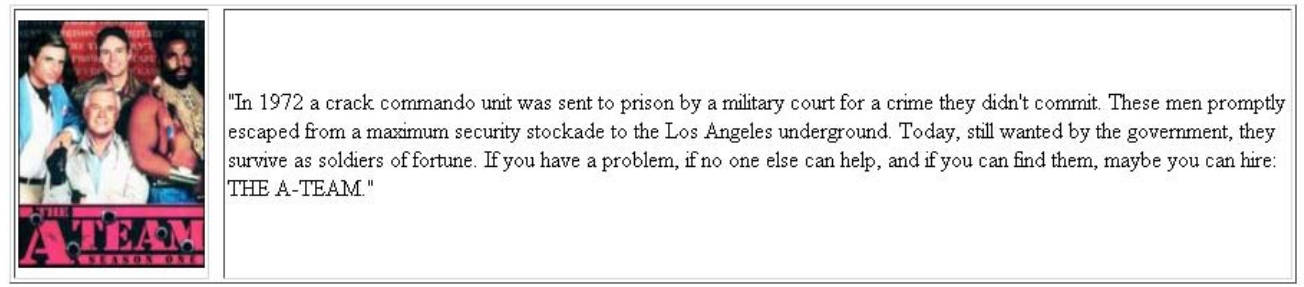

The other show in our library, which you will not watch tomorrow is:

Alfred Hitchcock Hour (see description below).
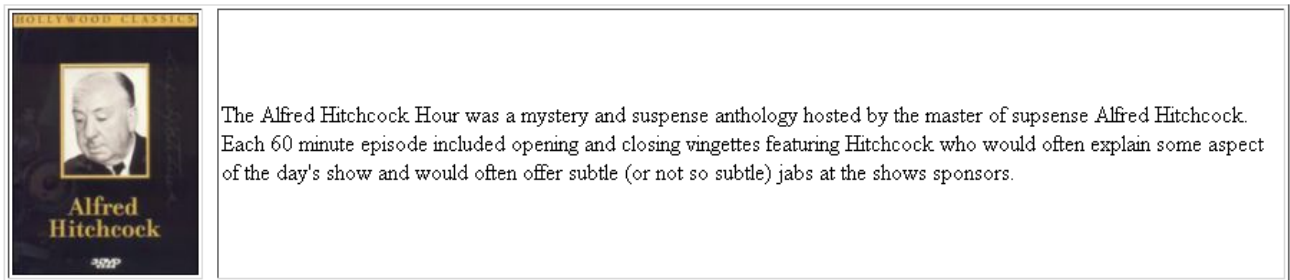

NOTE: We will monitor you tomorrow while you are watching the show to ensure that you are paying attention. If we find that you are not paying attention (because you fall asleep, are reading a book, etc.), you will only receive a show-up fee of $\$ 10$ and no additional $\$ 30$. 


\section{SCREEN 5 - Uncertainty Condition}

\section{Research Study}

\section{Now you must make the following choice, which we will hold you to tomorrow:}

Note that this choice is NOT hypothetical - it is a real choice!

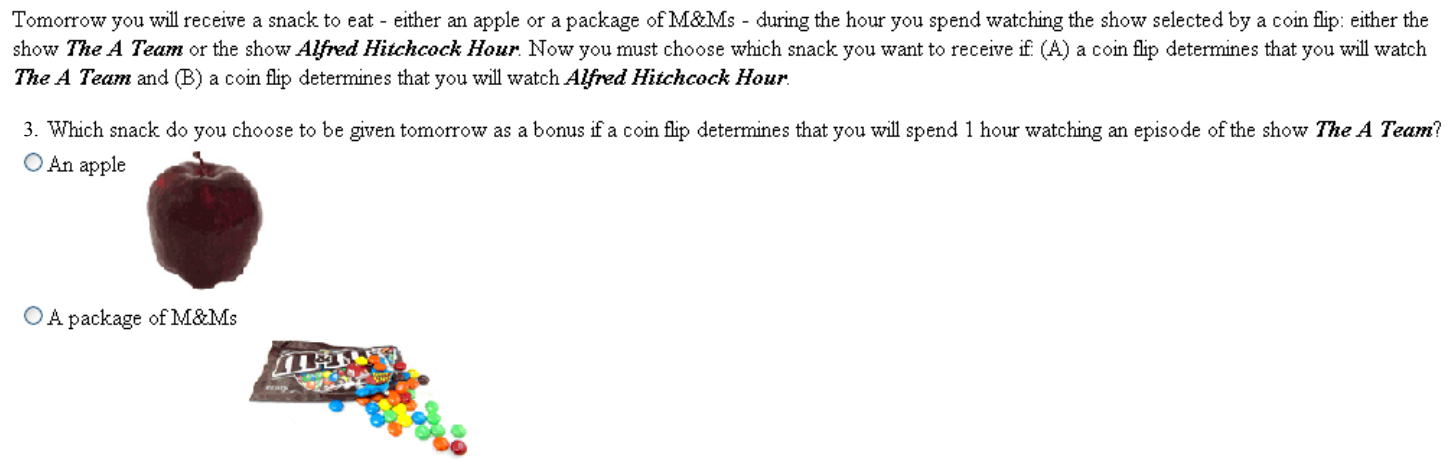

4. Which snack do you choose to be given tomorrow as a bonus if a coin flip instead determines that you will spend 1 hour watching an episode of the show Alfred Hitchcock Hour?

An apple

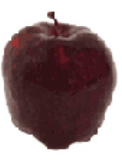

A package of M\&Ms

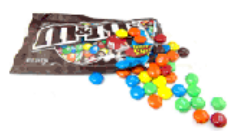

NOTE: You will not be allowed to leave the CLER lab with your snack.You must either eat it during the hour of film viewing or return whatever remains of it when you leave the room. 


\section{SCREEN 5 - Certainty Condition}

\section{Research Study}

\section{Now you must make the following choice, which we will hold you to tomorrow:}

Note that this choice is NOT hypothetical - it is a real choice!

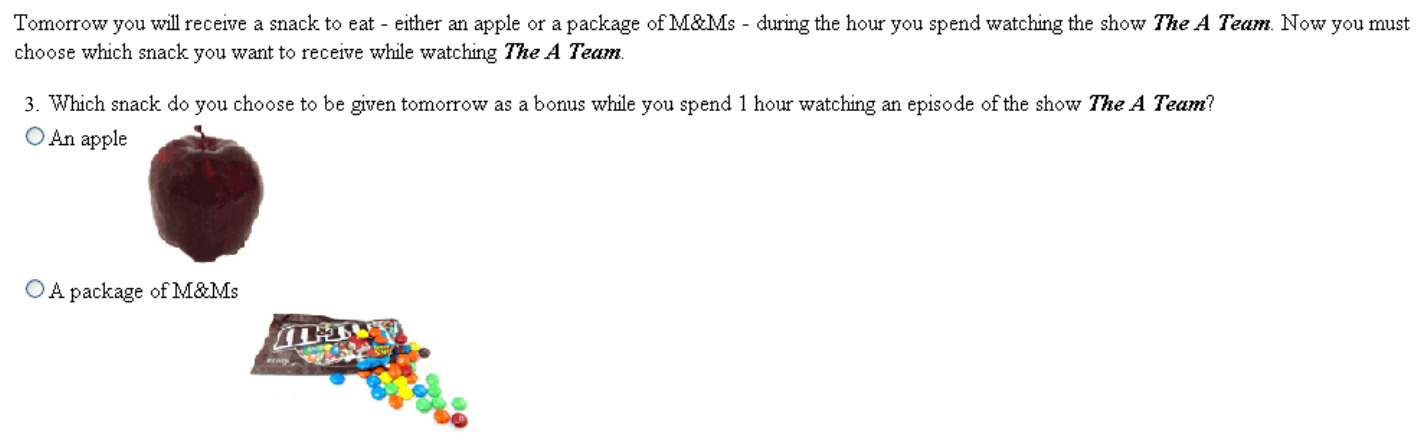

NOTE: You will not be allowed to leave the CLER lab with your snack.You must either eat it during the hour of film viewing or return whatever remains of it when you leave the room. 


\section{SCREEN 6 - Both Conditions}

\section{Research Study}

Below are a number of words that describe different feelings and emotions. Please read each item and select the appropriate answer next to that word. Indicate the extent to which you feel this way right now.

Use the following scale to record your answers:
(1) = Very slightly or not at all
(2) $=$ A little
(3) $=$ Moderately
(4) = Quite a bit
(5) = Extremely

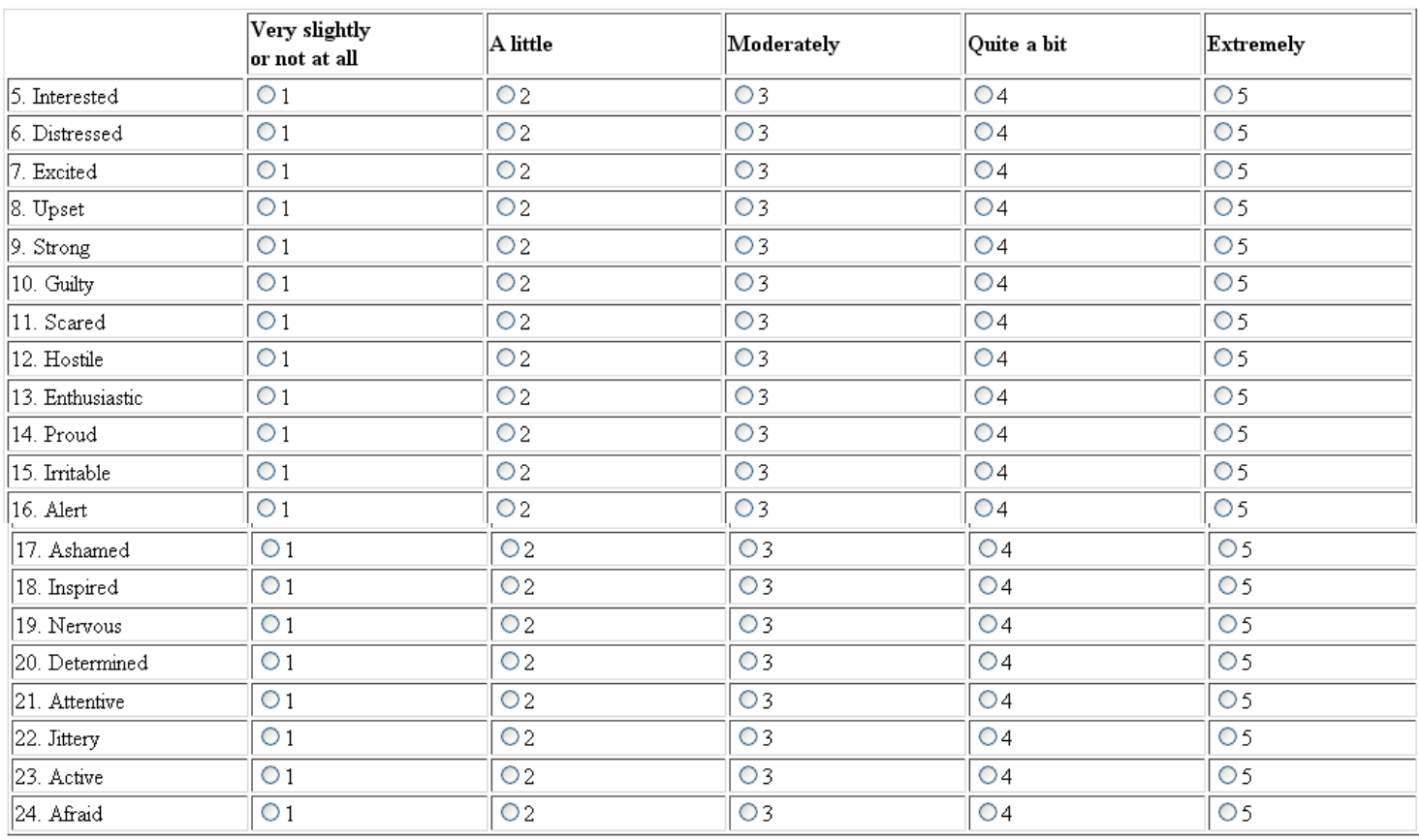

Submit Screen 5 


\section{Appendix F}

SCREEN 1 - Uncertainty Condition (following a prompt for the participant's ID)

Please briefly describe three to five things that you are most uncertain about in your life.

SCREEN 1 - Certainty Condition (following a prompt for the participant's ID)

Please briefly describe three to five things that you are most certain about in your life.

\section{SCREEN 2 - Uncertainty Condition}

Please describe in detail the one situation that has made you the most uncertain you have been in your life, and describe it such that a person reading the description would become uncertain just from reading about the situation.

\section{SCREEN 2 - Certainty Condition}

Please describe in detail the last time you sat in a quiet place (e.g., a park), and describe it such a way that a person reading the description would feel that they had been there just from reading about the situation. 
SCREEN 3 - Uncertainty Condition

Please describe the emotions that the thought of your being uncertain generally arouses in you.

\section{SCREEN 3 - Certainty Condition}

Please describe the emotions that the thought of sitting in a quiet place (e.g., a park) generally arouses in you.

\section{SCREEN 4 - Uncertainty Condition}

Please write down, as specifically as you can, what you think physically will happen to you as you feel uncertain.

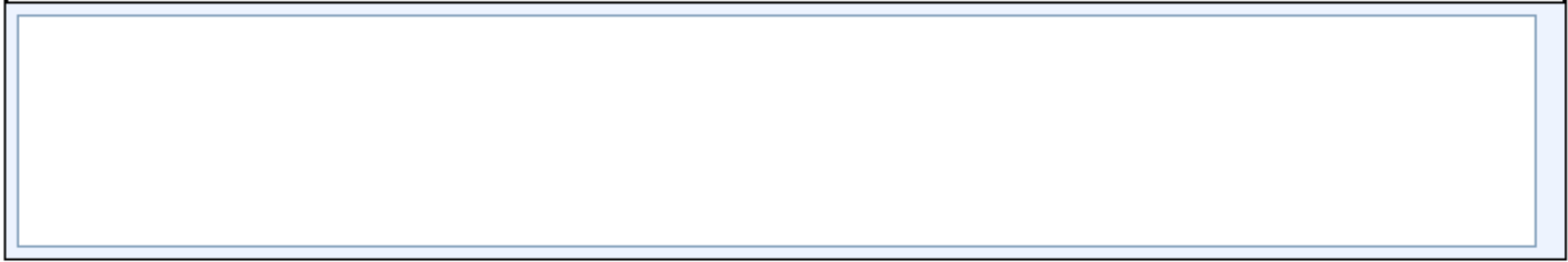

\section{SCREEN 4 - Certainty Condition}

Please write down, as specifically as you can, what you think physically will happen to you as you sit in a quiet place (e.g., a park). 


\section{SCREEN 5 - Both Conditions}

For each of the choices below, select the item that you most prefer. You should select one option in EVERY row. You should imagine that the item that you select will be delivered to you on the associated date.

\begin{tabular}{|c|c|c|c|}
\hline$\$ 10.00$ now & 0 & 0 & $\$ 15.00$ in one week \\
\hline$\$ 10.00$ now & 0 & 0 & $\$ 14.75$ in one week \\
\hline$\$ 10.00$ now & 0 & 0 & $\$ 14.50$ in one week \\
\hline$\$ 10.00$ now & 0 & 0 & $\$ 14.25$ in one week \\
\hline$\$ 10.00$ now & 0 & 0 & $\$ 14.00$ in one week \\
\hline$\$ 10.00$ now & 0 & 0 & $\$ 13.75$ in one week \\
\hline$\$ 10.00$ now & 0 & 0 & $\$ 13.50$ in one week \\
\hline$\$ 10.00$ now & 0 & $\mathrm{O}$ & $\$ 13.25$ in one week \\
\hline$\$ 10.00$ now & 0 & 0 & $\$ 13.00$ in one week \\
\hline$\$ 10.00$ now & 0 & 0 & $\$ 12.75$ in one week \\
\hline$\$ 10.00$ now & 0 & 0 & $\$ 12.50$ in one week \\
\hline$\$ 10.00$ now & 0 & 0 & $\$ 12.25$ in one week \\
\hline$\$ 10.00$ now & 0 & 0 & $\$ 12.00$ in one week \\
\hline$\$ 10.00$ now & 0 & 0 & $\$ 11.75$ in one week \\
\hline$\$ 10.00$ now & 0 & 0 & $\$ 11.50$ in one week \\
\hline$\$ 10.00$ now & 0 & 0 & $\$ 11.25$ in one week \\
\hline$\$ 10.00$ now & 0 & 0 & $\$ 11.00$ in one week \\
\hline$\$ 10.00$ now & 0 & 0 & $\$ 10.75$ in one week \\
\hline$\$ 10.00$ now & 0 & 0 & $\$ 10.50$ in one week \\
\hline$\$ 10.00$ now & 0 & 0 & $\$ 10.25$ in one week \\
\hline
\end{tabular}

